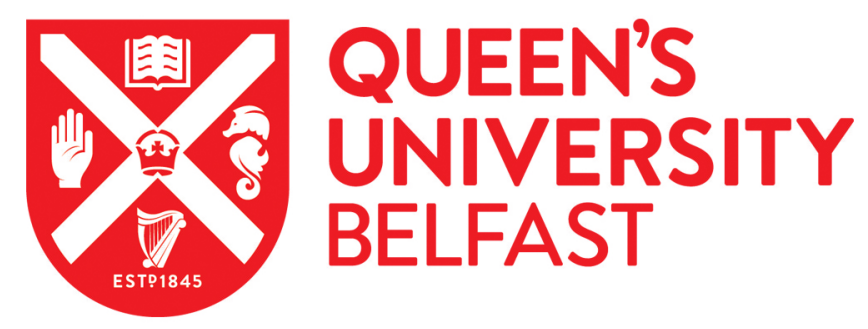

\title{
Trading-up on unmet expectations? Evaluating consumers' expectations in online premium grocery shopping logistics
}

De Kervenoael, R., Yanik, S., Bozaya, B., Palmer, M., \& Hallsworth, A. (2016). Trading-up on unmet expectations? Evaluating consumers' expectations in online premium grocery shopping logistics. International Journal of Logistics, 19(2), 83-104. https://doi.org/10.1080/13675567.2015.1023186

Published in:

International Journal of Logistics

Document Version:

Early version, also known as pre-print

Queen's University Belfast - Research Portal:

Link to publication record in Queen's University Belfast Research Portal

Publisher rights

Copyright 2015 International Journal of Logistics.

This is the pre-peer reviewed version of this article and may be used for non-commercial purposes in accordance with Wiley Terms and Conditions for Self-Archiving.

\section{General rights}

Copyright for the publications made accessible via the Queen's University Belfast Research Portal is retained by the author(s) and / or other copyright owners and it is a condition of accessing these publications that users recognise and abide by the legal requirements associated with these rights.

Take down policy

The Research Portal is Queen's institutional repository that provides access to Queen's research output. Every effort has been made to ensure that content in the Research Portal does not infringe any person's rights, or applicable UK laws. If you discover content in the Research Portal that you believe breaches copyright or violates any law, please contact openaccess@qub.ac.uk. 


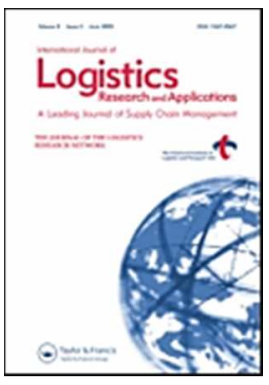

\section{Trading-up on unmet expectations? \\ Evaluating consumers' expectations in online premium grocery shopping logistics}

\begin{tabular}{|r|l|}
\hline Journal: & International Journal of Logistics \\
\hline Manuscript ID: & CJOL-2014-0033.R2 \\
\hline Manuscript Type: & Theory Paper \\
\hline Keywords: & retail, logistic, emerging market, grocery \\
\hline \multicolumn{3}{c}{} \\
\multicolumn{3}{c}{$\begin{array}{r}\text { SCHOLARONE } \\
\text { Manuscripts }\end{array}$} \\
\hline
\end{tabular}




\title{
Online premium grocery shopping:
}

\section{Evaluating consumers' logistical expectations}

\begin{abstract}
Current logistic practices regarding online grocery underplay demand-led models and conditions in large emerging markets metropolises such as Istanbul. These include raising income, access to technologies, transport difficulties, changing retail provision, and food culture. The study incorporates demand for premium products defined as comprising a variety of higher quality and unique products including organic ranges, healthy options, allergy free, and gourmet products through an online grocery model $(n=356)$ that integrates a novel view of home delivery (HD) in Istanbul. From a logistic perspective our model incorporates any products from any online vendors broadening the range beyond listed items found in any traditional online supermarkets. Data collected through phone survey and analysed via structural equation modelling suggest that the offer of online premium products significantly affects consumers' delivery logistics expectations. We identify the emerging geography of logistic models which respond to consumers' unmet expectations using multiple sourcing and consolidation points.
\end{abstract}

Key words: emergent markets, logistics, premium products, e-shopping, retail geography. 


\section{1- Introduction}

Logistics forms a significant dimension in retailing, yet much of what we know about retail spatial behaviour is centred on fixed-unit food stores. Increasingly, however, retailing is bound by, and interconnected with, rapidly changing local geography and consumption practices. Logistic associated with traditional bricks and mortar stores may struggle to meet consumers' trading-up expectations while at the same time, new styles - and locations - of dwellings are even challenging traditional online retail business operating models. While there can be little doubt that technological revolutions in communications have eliminated some of the constraints of place-based retailing and re-defined distance, little is known of trading-up expectations in emerging large metropolises. A growing concern exists that current logistic operational practices do not adequately reflect the micro socio-spatial changes in the urban environment of most post- 1990s cities in emerging markets. The vibrant nature of these emerging market ecosystems is a theoretically and empirically rich domain; the development of metropolises such as Istanbul is at what Bouzarovski, Salukvadze, and Gentile, (2010) termed "a developmental breakout phase" and requires ever more innovative strategies to create mechanisms that cope with increased dwelling densities, traffic, associated pollution and post-consumption waste management. In these markets, retailers are facing dynamic environmental conditions affected by new, more informed consumers via a rapid penetration and usage of the Internet often via mobile devices (Deloitte, 2010). Meanwhile, the food industry is far more concentrated than 20 years ago; the latest logistic technologies are implemented by some (RFID, QR codes), resulting in leapfrogging of traditional supply chain management practices (PWC, 2012). Yet, despite - or perhaps because of - a rather opaque form of urban planning and retail infrastructure development, often emerging after the creation of initial settlements and dwellings (Punakivi and Tanskanen, 2002), the remits of the 
main actors, namely online retailers, logistics firms and urban planners, are now converging and increasingly interconnected, calling for the development of new conceptualisation of eservice logistic management. The above problem settings can be recognized as variants of the well-known vehicle routing problem, which is studied extensively in the operations research and management science literature. Variants of the problem include the cases with or without delivery time windows, vehicle capacities, deterministic or stochastic order locations, split deliveries, and simultaneous pick-up and delivery among many others. We refer the interested reader to the surveys by Nagy and Salhi (2005, 2007), Parragh et al (2008a, 2008b) and Braysy and Gendreau (2005a, 2005b).

Under these dynamic conditions, a knowledge gap exists in the retail technology analysis and strategic logistics management literature regarding the development of online retail firms' logistics operations (Tsou, 2012; Kotzab and Teller, 2003). Such a gap must take into account (i) demand-led changes in emerging market condition (counter-intuitively often leading to the need for premium products to be made available), (ii) a loose legal environment, and (iii) socio-spatial changes in the built environment of most post 1990s cities (Cheema and Papatla, 2010). Traditional bricks and click stores may struggle to meet consumers' trading-up expectations.

According to Kapferer and Bastien (2009a), brands are catalogued along a top-down scale ranging from (a) luxury products and brands (centred on prestige e.g. Hermes), (b) Masstige brands (e.g. BMW, Starbucks, and Zara), (c) Premium brands (e.g. Hyatt, Kroger, Tesco Finest, Cadbury) to (d) Medium level brands (Tesco Budget) (Silverstein and Fiske 2003; Keller 2009). Brands vary along a continuum in their main constitutive characteristics including price, quality, rarity, extra-ordinariness, aesthetics and symbolism. As such, premium brands have to remain pragmatic regarding their value-for-money ratio. Both the trading-up strategy of masstige and premium brands and the trading-down strategy of luxury 
brands make luxury-like products accessible for middle-class consumers (democratization of luxury) (Tungate, 2004). Democratic luxury products are characterized by Kapferer and Bastien $(2009 b, 314)$ as "ordinary items for extraordinary people, which are at the same time extraordinary items for ordinary people".

Grocery retailers use premiums to attract and retain consumers who would not normally buy a product or service on this occasion or only the lower priced equivalent from third party brands (private labels). As such, premiums are used to introduce new products, provide extra appeal in special sales events, meet competitive prices, provide copy appeal, and promote larger size units. Retailers used premium brands to boost sales hence basket size and overall profitability. In particular, premium offerings are including not just higher quality and unique or distinctive items (often under the label choice, select, finest or signature), but also natural and organic, better-for-you and international and gourmet/specialty products (Kapferer and Bastien, 2009b). Taken together, a Premium brand is a brand that holds a unique value within a specific market and or a particular audience (e.g. SAAB, Tesco finest Belgian chocolate salted caramel \& hazelnut ice cream). Grocery retailers also purse their premium positioning through accreditations (e.g. Fairtrade, Free range, outdoor bred, and Linking Environment And Farming scheme (LEAF)), demonstrating their lack of compromise on quality standards or sourcing integrity to consumers compromise (de Kervenoael et al, 2011).

In our case, premium products (sourced from multiple- online- vendors, i.e. beyond listed items found in any supermarket) carry specific expectations for logistics. First, storage temperature must be guaranteed together with the integrity of the packaging for transportation (e.g. chocolate items- not broken / cracked - as well as exterior visuals - the box's aesthetic that can be displayed for guests). Second, extra care is expected during handling and mixing with other items in the shopping cart (compression and leakages). Third, online, premium 
products will be searched for with great care -- including review of comparisons and feedbacks from other consumers -- a process thus raising expectations (no-substitutions) of consistency and quality. Fourth, an overall logistic premium service may also be expected from a particular type of delivery van (MINI, for example, launched the world's first premium compact delivery van for Urban-Hipster), courier (not driver) uniform, cleanliness and communication training to online tractability (stock level), clear paperwork (insurance), express delivery and return policy providing a complete premium experience.

As such, the question becomes: under the conditions of an emerging market metropolis, can premium products through multi-sourced supply with a larger basket and consolidated flexible delivery lead to growth of online supermarkets sale?

While much research in the retail grocery sector has emphasized technology-led supply resource planning, comparatively little is known about how consumers' expectations - shaped by rapid social changes - have evolved. Expectation has been defined as a state of expecting or looking forward to an event as about to happen (Vroom, 1964). Empirically, expectations are important in shaping operational performance potentials and are attributed to defining the global marketplace opportunities. Motivation and risk where a reasonable benefit or performance is foreseen drive expectations (Elliot and Fowell, 2000).

Consumer trade-up choices and expectations are stretching the capacity of the online retail business operating models. Two operational models dominate the market - in-store picking and the distribution centre. Some extant studies have questioned whether or not both models are operationally ill-equipped, individually, to account for the changing demography, growing choice and increasing expectations for the provision of premium offerings (Hays and Keskinocak, 2004). The nature of these premium offerings, along with the operational limitations of the traditional online grocery models, has resulted in a new hybridization operational model emerging in practice (Kim et al., 2010). Hybrid models involve multiple 
sourcing actors, order consolidation points, and flexible collection points for consumers leveraging the complexity of the "final delivery mile" (Berman and Thelen, 2004; Gulati and Garino, 2000; Prasarnphanich and Gillenson, 2003; Saeed et al., 2003; Constantinides, 2004). In such settings, the perceived, unmet expectations of the consumer may predict online premium provision and operation management opportunities. In particular, we are also interested in how collective power, and uncoordinated and unmet expectations, can converge to shape new future practices that dynamically alter field-level retail logistics practices.

This study's objectives are therefore to present a theoretically justified research model encompassing both supply-led and demand-led attributes of online shopping behavior. This study extends research on identifying potential for hybrid online provision through multiple sourcing of premium products consolidated and delivered by users' current online supermarket, identifies the consumer expectations for online grocery premium provision, examines the supply and demand-led drivers of consumer expectations. We empirically demonstrate the significance of relationships between these factors using a sample of 356 online grocery consumers (i.e., regular online shoppers) in Istanbul.

The contribution of this study is threefold. First, in the logistics and distribution field, researchers have now begun to examine the demand-led processes by which consumers shape online provision amongst retail offers that provide hedonistic consumption, a scenario thus enabling simultaneous improvement in the economic performance of e-retail firms' strategy (Chen et al., 2007). This paper extends this work by including premium products not traditionally listed by supermarkets but sourced from elsewhere in the supply chain. Second, while much research has emphasized technology-led supply resource planning, comparatively little is known about how consumers' expectations shaped by changes in a socio-spatial environment may consequently alter online technology logistics provision. This study addresses this limitation. Following Ansari and Phillips (2011), we add to the understanding 
of the effects of crowd-sourcing by uncoordinated activities resulting in a critical mass and momentum so strong that the retail logistics practices at field-level are impacted. Third, although several dimensions developed in previous supply-led studies have touched on the logistic operational aspects emerging from developments within online provision, not one exclusively regards the potential impact for FMCGs as a basket of products.

The paper proceeds as follows. A brief survey of the theoretical and empirical literature on consumer choice in relation to the online grocery field is undertaken and exemplified by a synopsis of the logistical issues in Turkey and Istanbul. Research hypothesizes and methods demonstrate the usefulness of integrating premium products with advanced logistics.

\section{2- Conceptual underpinning}

A variety of studies have analyzed e-grocery models and behaviors: see for example Punakivi and Tanskanen (2002) and Agatz, et al, (2008) for good reviews. This study summarizes the key aspects that specifically relate to the research objectives. In the operations and information field, researchers have recently started to pay greater attention to demand-led processes by which consumers co-evolve and shape online retail provision (Keen et al., 2004; Macaulay et al., 2007; Murphy, 2007). Expectations for new provision are impacting the nature and scale of online retail operations. In turn expectation often links to motivation as "the explanation of choice made among different behaviors that are under central or voluntary control" (Vroom in Smith and Hitt, 2005, 247). In other words, once the channel is decided, what determines the direction and magnitude of shopping behavior, including the choices that are made among different providers and products available, is a result of expectations.

Historically, studies of online grocery provision draw on three distinct perspectives supply-led, demand-led and technology-enabled approaches. First, the supply-led operational research approaches encompass areas such as: collaborative models, including for example, 
material requirements planning (MRP), quick response (QR), efficient consumer response (ECR), vendor managed inventory (VMI) and collaborative planning, forecasting and replenishment (CPFR); management operation strategies for consolidation leading to fulfillment cost savings, global pricing, global ICT standards, inventory and capacity information sharing; global efforts along the supply chain such as international sourcing to generate diversified order forecast, promotion and sale information sharing towards quality improvement and reduce "concept-to-market" product cycle time- all have implications for choice (Chen et al., 2007).

Within these studies, a general understanding emerges of a supply-led impact of choice on online grocery provision. Empirical studies show that grocery retail firms emphasize similarities and commonalities between store-based and online choice provision (Burt and Sparks, 2003). In effect, this analogy results in the dominance of in-store picking operational model. While alternative operational models exist, studies show that the economies of scale do not always support the full independent distribution center system for online provision (recall Web Van that failed in 2001) (Keen et al., 2004; Lankenau et al., 2006).

Regarding online provision, the strength of the traditional operations systems constrains grocery retailers; that is, meeting local store-based competitive pressures forces the centralization of administrative processes, standardization and the uniformity of provision that precludes wider non-listed multi-sourcing partners. Based on operational advantage (i.e., size and dominance), grocery retailers selectively increase provision, but in doing so, business operating models often reduce varieties of localness. Empirically, the limited and relatively small provision that individual online retailers operationally deploy in practice creates a system that encourages a highly limited number of large approved standardized sourcing suppliers. 
Online, in the case of a basket of often low priced goods such as groceries, a wider choice being a click away (i.e., going to other e-retailers in the middle of the shopping experience) is not common practice (Hsiao, 2009). For consumers, this practice means that once inside an online retailer site, a captive provision set exists. This type of supply-led controlled provision greatly increases retailers' buying power and concentration in the industry (Competition Commission, 2008). From this perspective, choice provision is a measure of operational supply-based performance.

The supply chain literature examines a range of operational choice models ranging from brick and click, pure play to third party logistics (Murphy, 2007). In that literature, provision represents the awareness and capability of retail firms to identify the total supply provision accessible. At one level, expectations revolve towards a simple updated list: who can collaborate in supplying provision range? These inquiries evaluate the various trading partners and channels available ranging from take-away restaurants, markets, forecourts, farm shops, grocery stores and other trading partners.

A second, demand-led explanation of online grocery provision emerges. This literature finds that consumers' expectations form the "real" choice between and within channels, stores and brands (Chen et al., 2007; Clarke, 2000). Indeed, nowadays, online consumers increasingly question the lack of divergence between store-based and online provision. Studies show that online retailers have operationally responded in different ways. Measures include, but are not limited to, offering unique multimedia and often interactive consumer experience (image differentiation), listing novelty and limited edition not available offline (limited customization), responding quickly to demand for specific information (one to one relationship with current and potential consumers) (Keen et al., 2004; Macaulay et al., 2007). In effect, online consumer demands increase the operational complexities from the 
heterogeneity in the provision of goods (e.g., premium offerings), while at the same time, challenging routinized operational models that are efficient and effective.

In contrast to the supply and demand-led approaches, a final approach, a technologyenabled explanation, bears directly on the issue of online grocery provision (Burt and Sparks, 2003; Ramus and Nielsen, 2005). This technology-enabled explanation attributes greater transparency over online grocery provision. In this regard, the literature highlights two challenges associated with provision: a restricted range with compatible standards (i.e., ready to accept contractual terms), technologies, and an operation model based on volume that excludes multiple smaller sources of supply.

Studies such as Elliot and Fowell (2000), Shih (2004), and Constantinides (2004) point to the role of both standardization and future IT investment, and global legislation and regulatory concerns (e.g., privacy concern regarding radio frequency ID, global positioning system and geographic information system usage) in relation to collaboration. Therefore, although the results of early studies on the role of technology-enabling seemed promising, recent studies conclude that evidence of the hypothesized effect of IT on provision is weak at best.

Two observations emerge from the three literatures. First, the supply side studies note that firms must secure competitiveness and gain market legitimacy from product differentiation, while simultaneously having a similar product provision, to meet consumer expectations. However, little attention exists towards consumers' unmet expectations; that is to say, the difference between initial expectations (or needs) and actual experiences on the online grocery provision. Studies have pointed to the ways that online retailers resist widening access towards low volume provision to maintain operational efficiencies. While retailers use “cross-docking" processes, whereby suppliers aggregate bulk broken pallets and label them according to their destination store, thus leading to the direct re-routing of goods to the 
appropriate transport without leaving the distribution center loading bay, these processes significantly differ from consolidation points that involve an individual consumer ordered basket, permitting multi-store sourcing depending on stock level, and multi-providers' sourcing through non-listed partners aggregated within a single fulfillment operation.

Second, the literature does not discriminate provision "between and within" online retailers as a unit of analysis for study. Studies mostly discriminate between discretionary operational sourcing power among many products and providers or on the effects of consolidating the sourcing operation. Understanding this nuance plays an important role in the subsequent analysis designed to evaluate the expectation for premium product provision the online grocery market. Traditional operational models may result in consumers experiencing less of desire rather than anticipation (i.e., unmet expectations).

Significantly, though, premium products have specific attributes that may encourage regular provision volume as an important aspect towards operational viability. In other words, "when consumers have tasted luxury [premium in this case] in whatever they are, it is very difficult for them to turn away from it" (Kapferer and Bastien, 2009, 16). Premium, upper range, mass luxury, super premium, opulux, masstige and trading up raise prices and subsequently operational margins. This type of provision opens new growth opportunities for online retailers including a new set of relatively wealthy buyers, young and eager to create the powerful impressions that demonstrate access to the world of premium products. Increasing the provision of premium products, offers accessibility to completely new innovations, to new cultures, emotions and desires all raising the online retailers' brand image. This argument is commensurate with the FMCG product practice (e.g., L'Oreal, P\&G) that aspires to be a "true premium" for everyone (Silverstein and Fiske 2005).

\section{From traditional logistic relevance to emerging market e-strategy models: Turkey}


We now turn to our case study where powerful retailers may be missing the rise of substantial purchaser power of an emergent market. Structurally, however, though emergent markets may be inherently receptive to e-grocery per se, it does not follow that standard operating models can merely be imported. Western e-grocery models are primarily based on in-store picking or distribution centres. However, as with click and collect, the former implies the existence of a suitable store chain network; the latter, costly new-build. More suited to Istanbul might be a system involving multiple sourcing actors but, with ideally, a single payment made for all goods. Spatially, order consolidation points leading to a single delivery, and/or flexible collection points within a set of possible delivery locations (as used by courier services such as UPS or FedEX), might maximize consumers' expectations of convenience and thus reduce operational duplication.

Istanbul, Europe's largest city, demonstrates how the retail system may be required to modify its approach to meet the aspirations of a rising dispersed global middle class (Eraydin, 2011). One currently very high profile and relevant spatial aspect is the privatization of public spaces - malls - and the creation of secured 'gated communities' within the city. This phenomenon sits alongside a rather opaque form of urban planning and retail infrastructure development, often emerging long after the creation of initial settlements and dwellings (Punakivi and Tanskanen, 2002). Rising incomes, multiply-sourced premium products, and consolidated flexible home delivery ought to lead to the growth of online supermarket sales. Products could include premium products not traditionally listed by supermarkets but sourced elsewhere in the supply chain (the Amazon affiliate marketing principle). This resonates with the macro-economic fact that, as of 2011, Turkey's GDP per capita is about twice that of China and its growth rate in 2011 is second to China (Deloitte, 2010). According to Planet Retail, the turnover of the retail sector in Turkey in 2006 was $\$ 136.9$ billion rising by 2010 to $\$ 199$ billion. Numerically, the retail sector is, however, still dominated by a large number of 
small, independent, and single-location retailers. Capital accumulation is undersized, technologies used by retailers and business organizations are small-scale and most products and services are basic. Only in 1987 were the first two large supermarket brands established: Migros and Gima. In Istanbul, the first hypermarket, cash and carry Metro, opened in 1988. Despite the rapid development of modern retail formats, including hard discounters, supermarkets' share remains well below the $25 \%$ taken in most European markets. Alongside these trends, on the consumer side, since 2000 a tremendous growth in Internet usage $(+700 \%)$ and a rapid increase in online shopping activity have occurred. According to the Interbank Card Centre, in 2008, online transactions were already of $\$ 1.2$ billion with a projected increase to $\$ 2.2$ billion by the end of 2012 . Half of the 35 million consumers use the Internet for shopping (Aydemir, 2010).

To respond to this rapidly evolving environment, goods might best be supplied by vendors/suppliers from multiple locations in the supply network but delivered to each customer's designated delivery address as a consolidated order (Ugurlu et al., 2013). Any store could be the locus of such provision. The development of collection and delivery points (CDPs), either unattended in the form of locker points (e.g. shared reception box concept) or attended service points (e.g. gated community entrances), would generate cost savings (e.g. mileage, capacity utilization) and possibly more linked shopping. Here, the importance to emerging markets of gated communities with security and ground services lies in how this reality can be leveraged. Thus, multiple trucks/ fleets may synchronize their movements to complete the basket of items on a customer's shopping list. These trucks will then meet at "transfer points" also regarded as collection and delivery points (CDPs) to consolidate items from multiple vendors. These problem settings can be recognized as variants of the wellknown vehicle routing problem. We refer the interested reader to Ugurlu et al, (2013) and 
Daugherty (2011) as the details of these problems and the associated models extend beyond the scope of this paper.

\section{Research model and hypotheses}

This paper's research model draws together constructs from demand-led models (Clarke et al., 2006) and supply-led models (Collier and Bienstock, 2006b; Oh and Teo, 2010; Richey et al., 2008; Rotem-Mindali, 2010). Traditional constructs include time management, convenience, resistance to change, promotion, logistic operational procedures expectations, and collection around and outside the home. The model in this study also includes the novelty of premium products (Kapferer and Bastien, 2009; Silverstein and Fiske, 2005) and an attribute to control for overall local retail infrastructure impact.

This study defines online provision as the business management integration of organizational procedure, convenience, promotion, time management, resistance to change, local retail infrastructure, collection points, and premium expectation that create market opportunities enabling online shopping and the realization of online consumers' purchase intention. Based upon the literature, the following sub-sections describe constructs' definition and related hypotheses. Figure 1 presents the conceptual model to be tested.

\section{Insert Figure 1 about here: A MODEL OF CONSUMERS' EXPECTATIONS FOR}

\section{ONLINE RETAIL PROVISION DELIVERY}

\section{(1) Intentions for Online Grocery Purchases}

On the supply side, retail grocery competition has intensified with the emergence of online provision and transnational retail firms, creating higher, often dispersed, purchase expectations (Ha and Stoel, 2009). At the same time, increasing economic prosperity has commensurately increased consumers' expectations for hedonistic online provision on the demand side. Both theory and empirical support exists between intention to engage in 
behavior and actual behavior. In accordance with existing studies, the study uses behavior. In delivering online grocery, operationally the provision must be complicit with operational procedure requirements (e.g., cleanliness, refrigeration for chilled and frozen goods). Thus, retail firms' operational procedures for provision must meet strict handling requirements as part of consumers' expectations. Retailers that respond or already demonstrate a high level of operational procedure development can expect consumers to integrate even greater expectations of operational procedure progress in their intention to make further purchases. Consumers relate fulfillment of future expectations with their future intention to purchase, encouraging retailers to adopt a balanced approach to relationship building intention as a surrogate for actual behavior (Park and Kim, 2003; Constantinides, 2004). From our considerations, we devise the following hypotheses:

H1a: The higher the consumers' expectations for online logistic operational procedures, the greater the intention to purchase.

Expectation for convenience is another determinant of online grocery provision. Convenience includes distance and access, physical capabilities, time management and frequency, and integration with other commitments (Jackson et al., 2006; Rohm and Swaminathan, 2004; Oh and Teo, 2010). Thus, retail firms' operational provision must be cognizant of online consumers' expectations for convenience.

H1b: The higher the consumers' expectations for convenience, the greater the intention to purchase.

Empirical models show support for consumer bipolarization in online environments not only a negative customer reaction to dual pricing appears but support for expanding the operational provision of the online value proposition is also present. That is, while online promotions are traditionally enhancing the perception of price and quality (Darke and Chung, 2005), the provision of promotions including but not limited to, free samples, tailored 
packaging, bonus packs, and unique online complimentary offers, often strongly determine online grocery provision (Close and Kukar-Kinney, 2010; Rohm and Swaminathan , 2004). Thus retail firms' operations must be congruent with online consumers' expectations for exclusive promotions.

H1c: The higher the consumers' expectations for promotion, the greater the intention to purchase.

\section{(2) Expectations for Premium Offers}

Consumers' expectations calculate the utility as well as meaning, and logistics operations essentially facilitate the provision of both, especially in the premium market. Unlike price offers, however, premium purchases involve greater fulfilment costs and risks regarding online logistic operational procedure provision (Collier and Bienstock, 2006). Subsequently, the expected convenience of the logistic provision comprises the efficient and timely delivery of online goods (Rohm and Swaminathan, 2004). Furthermore, good logistics - especially if driven by exclusive online promotions (e.g. free shipping, secure/special shipping and delivery timing upgrades) are a key determinant of online consumers' expectations (Silverstein and Fiske, 2005). Lastly, the literature contends that operating a set of collection points across multiple locations is essential to the online provision (Punakivi and Tanskanen, 2002). Therefore, we suggest the following four hypotheses:

H2a: The higher the consumers' expectations for online grocer's logistic operational procedure provision, the greater the expectation of premium offers.

H2b: The higher the consumers' expectations for online logistic convenience provision, the greater the premium expectation.

H2c: The higher the consumers' expectations for online logistic promotion provision, the higher the premium expectation. 
The literature contends that operating a set of collection points across multiple locations is an integral part of the online provision (Punakivi and Tanskanen, 2002). Theoretical and empirical studies identify three operational models of collection: home collection, store pickup and at an unmanned, secure drop box. Studies show that these approaches are operationally well-equipped, collectively, to account for non-premium product offerings; however, this study hypothesizes that such models may be ill-equipped for the increasing consumers' expectations for premium offering provision (Agatz et al., 2008; Kamarainen and Tanskanen, 2001). Premium provision management models that do not guarantee the integrity of the goods at the final destination, that do not signal positive impression cues at the manned points of collection, and that do not attach a social meaning to the operation are less likely to meet online consumers' expectations. A negative relationship is expected, towards alternative collection points as they do not allow control of the premium goods by consumers

H2d: The lower the consumers' expectations for online unmanned collection points' provision, the greater the premium offer expectation.

\section{(3) Expectations for Online Promotions}

Resistance to change is a long established idea in the technology acceptance literature (Venkatesh et al., 2003). Adopting habitual patterns of behaviors is an important determinant of exclusive online promotion provision. Although promotion provision opportunities are common in retail operation environments (Burt and Sparks, 2003), consumers are constrained by habitual shopping behaviors. Thus, operations management enables the basis for experimenting with new exclusive online promotion innovations. We must also recognize that the historic, embedded, retail structures mean that consumers may remain 'captured' by habitual shopping behaviours and stores: the latter, in emerging markets, often offer the attraction of free minibus transport (or free scooter delivery) to stores/picking points/home. 
Therefore we propose that:

H3: The lower the consumers' expectations of resistance to change for online provision, the greater the online logistic promotion expectation.

(4) Expectations for Online Convenience

Time management, especially in urban environments, is defined as "behaviours that aim at achieving an effective use of time while performing certain goal-directed activities" (Claessens et al, 2004: 262). Time management is becoming a strategic variable of the consumer lifestyle. It is recognized that the way consumers handle the passage of time and the pursuit of goals fluctuates widely. Consumers with multiple workloads (work and study, work and family) tend to multitask so as to balance priorities and necessities. In addition, the temporal requirements of work (e.g. dual income family) together with the constraints of metropolises such as Istanbul (e.g. traffic, commuting distances) are further structuring time (i.e. link activities on the go - link shopping) that from a logistic perspective require further integration of the supply chain and integration of activities by vendors. Global technologies have also increased competition (sourcing convenience) and demands for immediate availability of products and services at any time and any place. As time is intangible, what can be influenced is the way a consumer deals with time. Thus, online provision models encompass automated enterprise resource planning systems (Chen et al., 2007). This practice results in efficient linkages between 'back office' and 'front office' systems through user friendly web interfaces. A yet further dimension is that wealthy but time-poor online consumers in cities such as Istanbul are willing to pay premium prices to place online orders and delivery at home or at the office at any time of the day (Rohm and Swaminathan, 2004).

Thus, we propose the following hypothesis: 
H4: The higher the consumers' expectations of time management, the greater the expectation for online logistic convenience provision.

\section{(5) Expectation for Alternative Collection Points}

The provision of secure, often manned, collection points in key locations such as around the city centre transport nodes, busiest shopping streets and offices areas (e.g. financial centres) must be integrated into the operations management of the retail firm (e.g. underground car parks), located across multiple local locations to cover a metropolis of $12+$ million and to adjust to the increasingly complex mobile lifestyles. Moreover, local retail infrastructure service levels, quality, and experiences in boutique shops of international brands need also to be emulated online. Thus, we offer the following hypotheses:

H5a: The higher the consumers' expectations of time management, the greater the expectation for alternative collection points.

Local retail infrastructure affects consumer patronage (Palmer et al., 2010). Recognizing that consumers' expectations account for both utility and meaning in the shopping provisions (i.e., varying across special occasions, everyday top-up shopping and once a week main shopping), studies suggest that more established shopping routines will lead to greater expectation for online operation provision. Therefore the provision of flexible convenient, secure collection points becomes an attractive asset and source of operational advantage.

H5b: The higher the resistance-to-change in service quality regarding online grocery practices compared to offline, the greater the expectation for manned alternative collection points. 
The literature refers to the crucial operational process towards repeat purchase and sustainability as the last mile. Also options such as usage of neighbors, porters, security personnel offer potential alternative manned delivery points for consumers; online retailers resist these practices due to possible litigation, quality and insurance issues. In view of that bottleneck, for traditional grocery items, online consumers are open to convenient alternatives such as delivery points often located in convenient areas outside their home district on "their commuting routes".

H5c: The greater the constraint on collection points near the home, the greater the expectation for alternative collection points.

Lastly, when top-up shopping is difficult due to the low provision of retail infrastructure, which is often the case in newly developed areas, where retail infrastructure follow dwelling constructions, or in low density population areas, efficient alternative delivery points are paramount to online retail models

H5d: The lower the availability of local retail stores around home area, the higher the expectation for alternative collection points outside the home area.

\section{Methodology}

\section{(1) Data collection}

Data for this study were collected via a phone survey in 2010 handled by a highly ranked market research agency. Participants were adults residing in the metropolis of Istanbul where online grocery shopping by two large supermarkets and a wide range of independents has been available since 2001. The recruitment criteria were based on two combined factors: online grocery shopping of at least three times a year (self-defined by respondents) and, role as primary household shopper. Data were collected via a convenience sample during a onemonth (November) period $(n=356)$. 


\section{(2) Research constructs and Items}

The questions, except categorical ones, were measured on a 5-point Likert scale anchored by 1 (strongly disagree) and 5 (strongly agree). Six items relate to logistics organizational procedure expectations and were adopted from Ha and Stoel (2009) to tap into the general operational procedures including the cleanliness of the transport vehicle and delivery personnel, refrigeration, damage to items and payment security. Three items were developed from Punakivi and Tanskanen (2002) to address the 'last mile delivery' expectations of collection points outside the home area. Four items addressing resistance-to-change were developed based upon previous work by Oreg (2006) in order to assess the impact of offline service quality and behaviour on online grocery purchasing. Five items were adopted from Jackson et al. (2006) and Rohm and Swaminathan (2004) to measure convenience expectation. Three items based on Clarke et al. (2006) and Rohm and Swaminathan (2004) measured the time management preferences of online grocery shoppers. Three items related to logistic promotion expectation were developed following Close and Kukar-Kinney (2010). Three items intended to tap into the premium expectation of online grocery shoppers were developed based on Silverstein and Fiske (2005) and Kapferer and Bastien (2009) including innovativeness, price, product alternatives and online communities. Three items regarding collection points around home were based on Punakivi and Tanskanen (2002). Three items on local retail infrastructure level were based on Clarke et al. (2006). Three items on purchase intentions from Park and Kim (2003) were also included as well as the collection of demographic data. The survey was translated to Turkish and pre-tested in an iterative manner amongst a sample of colleagues and students. Based on feedback, some questions were amended for clarity. A market research company implemented the survey through telephone interviews. Full anonymity was provided following our institution's ethical guidelines.

\section{(3) Respondent demographics}


The study measured a number of demographic variables in order to categorize the respondents and provide some notion of external validity for the results (Plank et al., 1999). The age variable was divided into five groups; the largest respondent group, with a $53.7 \%$ was 25-34 years. Younger respondents up to 24 years of age constituted 15.7\%; respondents aged $35-44,22.8 \%$. Lastly, $7.0 \%$ of respondents were $45-60$ and only $0.8 \%$, more than 60 years. Gender was evenly distributed: $52.8 \%$ males and $47.2 \%$ females. Education levels were $48.9 \%$ with undergraduate degree and $38.5 \%$ with high school degree. Household income ranged from $42.9 \%$ between $2500 \mathrm{TL}-5000 \mathrm{TL}$ to $40.9 \%$ between $1500 \mathrm{TL}-2500 \mathrm{TL}$ $(1 \mathrm{TL}=1.8 \mathrm{USD})$. The metropolitan nature of the sample (upwards) biased the range but equates to many urbanite populations in emerging markets. Regarding dwelling, $79.2 \%$ live in multi-storey apartments; $19.4 \%$ in a secured site; and only $1.4 \%$ in a single villa within gated communities. Furthermore, $56.7 \%$ of respondents are homeowners and $41 \%$ renters. Finally, $41.3 \%$ of the respondents claimed that they had to fit their shopping delivery / collection around paid work with $92.5 \%$ working full time.

According to the data, the average online grocery shoppers' basket size is between 70 150 TL for $54.5 \%$ of the sample. Regarding frequency, 5-6 purchases per year represents $54.2 \%$ of the sample. Moreover, the data demonstrate that $38.2 \%$ buy up to $10 \%$ of their total grocery online, $24.7 \%$ buy $20 \%$ and $20.5 \%$ buy $30 \%$. A non-negligible proportion $16.5 \%$, buy online over $40 \%$ or more of their groceries.

\section{Results}

To ascertain the validity of the scales, confirmatory factor analysis (CFA) was conducted (Gerbing and Anderson, 1988). The CFA analysis confirmed that each construct had unidimentionality (low $\chi 2$, high p-value, and high-fit indexes). Convergent validity was also established as all items for each scale loaded significantly (with the lowest t-value being 3.978). Tables 1 and 2 present the scale items, correlations reliability, and descriptive 
statistics. The 10 factors identified include (1) expectation regarding logistic organizational procedure (2) collection points outside the home, (3) resistance to change, (4) convenience expectation, (5) time management, (6) promotion expectation, (7) premium expectation, (8) collection points around home, (9) local retail infrastructure and (10) purchase intention.

Insert Table 1 about here: Measures

And Table 2 about here: Correlations Reliability and Descriptive Statistics

\begin{abstract}
Relationships between the constructs in the model were tested using structural equation modeling. In our model $\chi 2=766.26$ with 411 d.f. Following Wu (2006) our model's goodness of fit index equal to 0.88 , with a normed fit index of 0.83 , an adjusted goodness of fit index of 0.86 , and a comparative fit index of 0.91 demonstrating a good fit. Lastly, the model's root mean square error of approximation at 0.047 also indicates a good fit. The path coefficient and corresponding t-values along with the fit indices are presented in Table 3.
\end{abstract}

Insert Table 3 about here: Results of the SEM

The results indicate that the model is robust since all items were loaded significantly at the 0.01 level on their assigned latent variable. Table 3 demonstrates that logistic organizational procedure expectation positively impacts e-grocery purchase intention $(\beta=0.15$, $\mathrm{t}=3.11$ ) confirming $\mathrm{H} 1 \mathrm{a}$; logistic organizational procedure expectation has a significant positive relation with premium expectation $(\beta=0.28, \mathrm{t}=3.89)$ supporting H2a. The hypothesized positive effect of convenience expectation on online grocery purchase intention $(\beta=0.11, \mathrm{t}=2.13)$ and premium expectation $(\beta=0.48, \mathrm{t}=5.52)$ were both also shown to be statistically significant respectively confirming $\mathrm{H} 1 \mathrm{~b}$ and $\mathrm{H} 2 \mathrm{~b}$. The paths from online logistics 
promotion expectation to online grocery purchase intention $(\beta=0.14, t=2.29)$ and premium expectation $(\beta=0.23, \mathrm{t}=2.63)$, respectively were significant as hypotheses $\mathrm{H} 1 \mathrm{c}$ and $\mathrm{H} 2 \mathrm{c}$. The path of collection points outside the home has a negative relationship with premium expectation $(\beta=-0.18, \mathrm{t}=-2.40)$, supporting $\mathrm{H} 2 \mathrm{~d}$. Time management has a significant positive effect on convenience expectation $(\beta=0.30, t=3.88)$ and a positive effect on collection points outside the home $(\beta=0.31, \mathrm{t}=4.42)$, confirming $\mathrm{H} 4$ and H5a. Resistance to change was shown to be negatively impacting online logistic promotion expectation $(\beta=-0.33, \mathrm{t}=-4.19)$ as hypothesized in $\mathrm{H} 3$, and had a positive relationship with collection points outside the home $(\beta=0.30, \mathrm{t}=4.11)$ supported H5b. Lastly, the question of collection points around the home is shown to be positively influencing, collection points outside the home $(\beta=0.29, t=3.89)$, supporting $\mathrm{H} 5 \mathrm{c}$ respectively, whereas collection points around the home are negatively impacted by local retail infrastructure $(\beta=-0.22, \mathrm{t}=-2.95)$ as hypothesis $\mathrm{H} 5 \mathrm{~d}$.

\section{Discussion}

As the scale and scope of new technology usage in online grocery provision increases, it is important to understand the interplay between the geography, technology and power in (online) retailing practice. The findings show that consumers' shopping expectations intensify pressures to hybridize the operating model for online grocery provision of retail firms. The analysis also provides empirical support that consumers have unmet shopping expectations in relation to the choice of range offered through online operations. Rather than price as the main driver of consumer shopping expectations, the findings illustrate the complex decision making behaviour displayed by consumers' shopping expectations for online grocery provision. This paper is therefore an important step in this respect. Our empirical analysis in Turkey revealed the effect of online consumers' general expectations in emerging market conditions as well as an evaluation of the rising importance for the provision of premium 
grocery products. We find that consumers' expectations led to intensified agentic tensions and pressures on e-retail firms to hybridize logistic operating models for online grocery provision. Our analysis also provides empirical support to the argument that consumers (in particular the millennial and generation txt) have unmet expectations in relation to the choice of goods, especially regarding access to premium products as the emerging online platform has created new shopping patterns regarding both information and experience (Rheingold, 2002).

The results suggest that the following aspects of online logistic grocery operation: (i) the value of delivery point flexibility both around and outside the home, (ii) the impact of the offline retail infrastructure services or lack of them, and (iii) premium provision. These attributes include the significance of premium provision offerings, multiple sourcing actors, order consolidation points, along with flexible collection points leveraging the complexity of 'last mile' delivery. Power differentials are thus reversed, giving consumers control over which products retailers list. Word of mouth (WOM) and social networking sites via wireless access mainly through Smartphone are providing unprecedented control by ensuring that consumer demands are heard and acted upon. Our findings also carry implications for online retail providers seeking to make sense of emerging complex online behaviour. Among the more notable issues would be the need to extend choice whilst reducing operational duplication in order to achieve logistical effectiveness within the new metropolis geographical settings. A way ahead would be a partnership perspective that fosters collaboration across business entities. Typically, however, online grocery retail firms appear to be reluctant to engage in such scenarios that apparently deviate from their core business model. Indeed, many do not permit customers to diverge from listed items, regardless of any demand-led premium expectations. In this paper, the mechanics of time management mediated by technology is considered. H4 underlines the technical aspect of online ordering through streamlined ordering process (flow) to reduce errors, thus allowing consumers to manage 
increasingly complex lifestyles. As such, it is fairly easy for respondents to evaluate and selfreport on their perception of classical website performance (organization, logic, and check out process). H5a deals specifically with the logistics aspect of time management related to 'having options'. For many consumers, stopping by the supermarket or accessing click \& collect may not be an option. Autonomy to shop for grocery items is often low in metropolises (e.g. lack of access to private transport, traffic preventing execution of one's original plan, location of large supermarkets, no fixed time for ending workday etc). In addition, in the case of grocery, household total needs have to be integrated, to acquire in one-time the maximum number of individually identified specific items, necessitating aggregation (multiple logins) to address the social context and personal mobility relations among individuals (Elms and Tinson, 2012). Taken together, alternative collection points offer a greater range of opportunities and a greater chance for one member of the family to collect the ordered grocery without changing one's schedule. Flexibility in a collection point is also relatively easy for respondents to identify as present, absent, or difficult/easy to specify on the website. Indeed, new field entrants such as Amazon are re-visiting such conventions (multiple addresses) with success and have created the notion of affiliate marketing (multiple sourcing vendors). The results identify a need for flexible delivery options to serve the dynamic socio-spatial environment in emerging markets. Our model specifically demonstrates that premium provision expectations and operational logistics are highly relevant in assessing consumer intentions towards online grocery purchases. However, we are concerned that current operational practices do not adequately meet the expectations of consumers in environments such as Istanbul. In Istanbul, the core actors have yet to venture truly in the wider digital ecosystem to fully understand the emerging role and potential of e-consumers. Powerful players may simply not be aware of the scale of change and the potential that it brings. The rapid growth of Yemeksepeti.com [a meal in a basket ] can be underlined here, as the main e- 
grocers have yet to integrate new wider field players in their organizational strategy (De Kervenoael and Dogerlioglu Demir, 2011).

The results also indicate the significance of advanced logistic operations models in extending choice and reducing operational duplication to achieve logistical effectiveness beyond traditional store planning systems. That is, logistic operational flexibility is a potentially rich source for profitably expanding consumer provision beyond the boundaries of the firm and the current limited choices. Indeed, studies on the recent success of the organic category, both food and non-food, demonstrate that price sensitivity has declined for premium products: a discovery that leads to a rethink of the traditional business model. Our results show that retail firms arbitrage of worldwide operations and information systems, for the most part directed towards cost reduction rather than increasing online grocery provision, may be un-justified. We suggest that the narrow view of provision adopted by online grocery providers should be broadened towards a partnership perspective that fosters collaboration across business entities, cross-functional teams, to improve logistical services. The end result would be a seamless, common share process that recognises the new momentum generated by consumers. The results, in turn, suggest a focus on total system performance rather than narrower cost based strategies and inclusion of the perspective of current and potential consumers would centralize consumer lead practices to new organizational strategies.

Viewed from another perspective, this study provides theoretical and empirical support for understanding which aspects or dimensions of consumers' expectations are critical (i.e. unmet expectations) to future business practices management innovation and planning policies demonstrating that consumers are now sufficiently strong (even if dispersed and uncoordinated) to significantly influence changes in the field. At the same time, however, this research indicates that online grocery retail firms will not necessarily engage in anticipating, experimenting, or determining which new consumer practices might result in a competitive 
advantage (Swidler, 1986). This lack of management innovation is perhaps because of (a) an oversight of the collective powers and roles of consumers and (b) a strong reluctance to see logistics partners as value-added associates under uncertain long term legal perspectives. Furthermore, myopic and management-centric views may under appreciate the powerful role of geography in shaping consumers' expectations.

Although the operations-enabling technologies are actually present (e.g. RFID, GIS, GPS), online grocery retail firms appear to be cautious and reluctant to engage in scenarios that deviate from their core business model and re-define firm boundaries (Lawrence and Phillips, 2004). This study appears to support the need for the new hybridization of a logistical operational model to emerge in practice encouraging technical interoperability a notorious weak point for e-grocers. The current logistic models do not permit customers to diverge from listed items, regardless of any demand-led premium expectations and hyperconnectivity with multiple providers. At another level, online provision is now driven by a multimedia global environment that encourages online retailers to go beyond their traditional pushing of technologies purely to grow sales. The operating models therefore must evolve to both meet the higher value expectations in the online provision via flexible delivery options that integrate emerging market dynamic socio-spatial environment away from the anticipated direction by the industry. As a result, our model specifically demonstrates that premium provision expectations and operational logistics are highly relevant in assessing the intention towards grocery purchase online creating social practice stickiness that may be difficult to reverse when the novel interrelationships among a broader set of actors is established. Concurrently, however, there is growing concern that while current operational practices do not adequately meet the expectations of consumers others consumers' practice that modify field-level custom and forces change are to be expected in other organization 
areas such as advertising, customer relationship management and new product development (von Hippel, 2005; Bijker and Law, 1997).

The hybridization of operating models. A final implication relates to whether both models -- in-store picking and the distribution centre -- are operationally ill-equipped, individually, to account for the changing demography, growing choice and increasing expectations for the provision of premium offerings in emerging market metropolises. This study appears to support the need for a new hybridization operational model emerging in practice. The current operational models do not permit customers to diverge from listed items, regardless of any demand-led premium expectations may lead to greater sustainable growth. The findings suggest that business operation models that facilitate premium sense making and, in the process, encourage appreciation of the local culture and acquisition of a premium products that ultimately facilitate and progress consumers' expectations. At another level, online provision is now driven by a multimedia global environment that encourages online retailers to think and go beyond their traditional listed suppliers, yet the controlling size of the major players seems to inhibit operational logistic innovation. Online grocery retailers do not provide a forum for future suggested provision and providers. The operation model therefore must evolve to both meet the higher value expectations in the online provision via multiple delivery options and integrate urban transport flows as well as existing retail infrastructures.

\section{Limitations}

Consider a number of limitations in the present study. The study here examines only the effects of expectation on online grocery provision. Studies show that retail firms operating within advanced institutional retail structures are diversifying into non-grocery provision (Dawson et al., 2006; Elms et al., 2010). The sample of the study is based in Istanbul within Turkey; urban scholars argue that firms and therefore associated studies are extreme in their 
adherence to urban areas, neglecting rural areas and the associated operational constraints. Third, this study did not explore the underlying psychological processes by which expectations and online premium provision in general, affect consumers. A different study may elicit the responses of managers to understand the specific operational and information constraints of the online operation models.

\section{Conclusion}

The results suggest that while traditional aspects of online logistic grocery operation remain important, the following are also significant: (i) the value of delivery point flexibility both around and outside the home, (ii) the impact of the offline retail infrastructure services or lack of it, and (iii) premium provision. These attributes include the significance of premium provision offerings, multiple sourcing actors, order consolidation points, along with flexible collection points leveraging the complexity of the last mile delivery.

From a managerial perspective we identify two strategic management implications:

The results indicate the significance of advanced logistic operation models in extending choice and reducing operational duplication to achieve logistical effectiveness. That is, logistic operational flexibility is a potentially rich source for expanding consumer provision beyond firm boundaries and current limited choices at a profit. Our results show that retail firms arbitrage of worldwide operations and information systems, for the most part directed towards cost reduction rather than increasing online grocery provision, may be un-justified. We suggest that the narrow view of provision adopted by online grocery providers should be broadened towards a partnership perspective that fosters collaboration across business entities, cross-functional teams, to improve logistical services at that the whole activity ought to become a seamless common share process. The results, in turn, suggest a focus on total 
system performance rather than the narrower cost based strategies and that strategies that include the perspective of current and potential consumers are needed.

At the same time, however, this research indicates that online grocery retail firms will not necessarily engage in anticipating, experimenting, or determining which new consumer expectations might result in a competitive advantage. This lack of management innovation is perhaps because of a strong reluctance to see logistics partners as value added associates under uncertain long term legal perspectives. Although the operational enabling technologies are actually present (e.g. RFID, GIS, GPS), online grocery retail firms appear to be cautiously reluctant to engage in such scenarios that apparently deviate from their core business model. The operating models therefore must evolve to both meet the higher value expectations in the online provision via flexible delivery options that integrate emerging market dynamic sociospatial environment. Inter-relationships and interdependencies introduced along the supply chain towards wider provision need to be integrated operationally and not resisted by online grocery retailers. The evolution of online retail provision is complex and operationally growing more sophisticated daily. Developments such as reverse logistics which can handle recycled products, storage of consumers' items (e.g., ski, windsurf board), and peer to peer exchanges are changing the meaning of logistics and the expectations consumers have of online operational models. Inter-relationships and interdependencies that introduced along the supply chain towards wider provision need to be integrated operationally and not resisted by online grocery retailers. Significantly however, concern is growing that current operational practices do not adequately meet the expectations of online consumers 


\section{References}

Agatz, N.A.H.; Fleischmann, M.; and van Nunen, J.A.E.E. 2008. E-fulfillment and multichannel distribution - A review. European Journal of Operational Research, 187: 339-356.

Ansari, S. and N. Phillips. 2011, "Text me! New consumer practices and change in organizational fields". Organization Science 22(6): 1579-1599.

Aydemir, A. 2010. “Turkey's Internet censorship problem", http://www.todayszaman.com/news217435turkeysinternetcensorshipproblem. html, Access: October, 2012.

Berman, B., and Thelen, S. 2004. A guide to developing and managing a well integrated multichannel retail strategy. International Journal of Retail and Distribution Management, 32 (3): 147-156.

Bijker, W.,and J. Law. 1997. Shaping technology/building society. MIT Press, MA, USA.

Bouzarovski, S., Salukvadze, J. and M. Gentile. 2010. A socially resilient urban transition? The contested landscapes of apartment building extensions in two post-communist cities. Urban Studies 48(13): 2689-2714.

Braysy, I., and Gendreau, M. 2005a. Vehicle touting problems with time windows, part I: Route construction and local search algorithms. Transportation Science, 39(1), 104118

Braysy, I., and Gendreau, M. 2005b. Vehicle routing problems with time windows, part II: Metaheuristics. Transportation Science, 39(1), 119-139

Burt, S., and Sparks, L. 2003. E-commerce and the retail process: A review. Journal of Retailing and Consumer Services, 10: 275-286 
Cheema, A., and P. Papatla. 2010. Relative importance of online versus offline information for Internet purchases: Product category and internet experience effects. Journal of Business Research 63: 979-985.

Chen, M.C.; Yang, T.; and Li, H.C. 20074. Evaluating the supply chain performance of ITbased inter-enterprise collaboration. Information \& Management, 44: 524-534.

Claessens, B.J.C., van Eerde, W., Rutte, C.G.R., Roe, A. 2007. A review of the time management literature, Personnel Review, 36(2):.255 - 276.

Clarke, I. 2000. Retail power, competition and local choice in the UK grocery sector. European Journal of Marketing, 34: 975-1002

Clarke, I., Hallsworth, A., Jackson, P., De Kervenoael, R., Perez del Aguila, R. and M. Kirkup, 2006. Retail restructuring and consumer choice 1. Long term local changes in consumer behaviour: Porthsmouth, 1980-2002. Environment and Planning A 38: 2546.

Close, A. G., and M. Kukar-Kinney. 2010. Beyond buying: Motivations behind consumers” online shopping cart use. Journal of Business Research 63: 986-992.

Collier, B. J., and C. C. Bienstock. 2006. How do customers judge quality in an E-tailer? MIT Sloan Management Review 48: 35-40.

Competition Commission. 2008. The Supply of Groceries in the UK market investigation.

Constantinides, E. 2004. 'Influencing the online consumer's behaviour: The web experience', Journal of Internet Research, 14 (2): 111-126.

Darke, P.R., and Chung, C.M. 2005. Effects of pricing and promotion on consumer perceptions: it depends on how you frame it. Journal of Retailing, 81(1): 35-47.

Daugherty, P.J., 2011. Review of Logistics and supply chain relationship literature and suggested research agenda. International Journal of Physical Distribution and Logistic Management 41(1): 16-31. 
Dawson, J.; Larke, R.; and Mukoyama, M. 2006. Strategic Issues in International Retailing. Oxon: Routledge.

De Kervenoael, R, and Kivilcim, Dogerlioglu Demir 2011. Championing co-production and co-creation of value: the Turkish case of "Yemeksepeti.com" i.e., "Meal in a basket.com”. Innovations: Technology, Governance, globalization Special Edition for the Global Entrepreneurship Summit, Entrepreneurship, Values, and Development, 7175.

De Kervenoael, R., Canning, C. Hallsworth, A. and Palmer, M. 2011. Challenging Market Conventions: Supermarket Diversification and Consumer Resistance in Children's Apparel Purchases”, Journal of Fashion Marketing Management, 15(4):.464 - 485

Deloitte, 2010. Hidden heroes: Emerging retail markets beyond China. 34 pages; A Consumer Business and Transportation industry report.

Economist 2013. The end of the space race, Britain's biggest retailer tries to adapt to fastchanging $\quad$ shopping $\quad$ habits, 20. http://www.economist.com/news/britain/21576441-britains-biggest-retailer-triesadapt-fast-changing-shopping-habits-end-space.

Elliot, S., and Fowell, S. 2000. "Expectations versus reality: a snapshot of consumer experience with internet retailing", International Journal of Information Management, 20 (5): 323-36.

Elms, J.; Canning, C.; de Kervenoael, R.; Whysall, P.; and Hallsworth, A. 2010. 30 years of retail change: where (and how) do you shop? International Journal of Retail and Distribution Management, 38, 11/12.

Elms J. and Tinson J. 2012 Consumer vulnerability and the transformative potential of Internet shopping: An exploratory case study, Journal of Marketing Management, 28 (11-12):. 1354-1376. 
Eraydın, A. 2011. Changing Istanbul city region dynamics: re-regulations to challenge the consequences of uneven development and inequality. European Planning Studies, 19(5): 813-83.

Gerbing, D. W., and J. C. Anderson. 1988. An updated paradigm for scale development incorporating unidimensionality and its assessment. Journal of Marketing Research 25(2): 186-192.

Gulati, R., and Garino, J. 2000. Get the right mix of bricks and clicks. Harvard Business Review, 78 (3) (May/June): 107-114.

Ha, S. and L. Stoel. 2009. Consumer e-shopping acceptance: Antecedents in a technology acceptance model. Journal of Business Research 62: 565-571.

Hays, T and Keskinocak, P. 2004. Strategies and Challenges of Internet Grocery Retailing Logistics. Kluwer Academic Publishers, Dordrecht, The Netherlands.

Hsiao, M.H. 2009. Shopping mode choice: Physical store shopping versus e-shopping. Transportation Research Part E, 45: 86-95.

Jackson, P., Del Aguila, P. R., Clarke, I., Hallsworth, A., De Kervenoael, R., and M. Kirkup. 2006. Retail restructuring and consumer choice 2 . Understanding consumer choice at the household level. Environment and Planning A 38: 47-67.

Kamarainen, V.; Saranen, J.; and Holmstrom, J. 2001. The reception box impact on home delivery efficiency in the e-grocery business, International Journal of Physical Distribution and Logistics Management, 31 (6): 414-426.

Kapferer, J. N. and Bastien, V. 2009a The specificity of luxury management: Turning marketing upside down", Journal of Brand Management 16, 311-322.

Kapferer, J. N. and Bastien, V. 2009b The Luxury Strategy. London: Kogan Page.

Keller, K.L. (2009) "Building strong brands in a modern marketing communications environment”, Journal of Marketing Communications, Vol 15, No 2-3, 139-155. 
Keen, C.; Wetzels, M.; Ruyters, K.; and Feinberg, R. 2004. E-tailers versus retailers: Which factors determine consumer preferences? Journal of Business Research, 57: 685-695.

Kim, K.K.; Park, S. H.; Ryoo, S.Y.; and Park, S.K. 2010. Inter-organizational cooperation in buyer-supplier relationships: Both perspectives. Journal of Business Research, 63: 863-869.

Kotzab, H., and C. Teller. 2003. Value-adding partnerships and co-opetition models in the grocery industry", International Journal of Physical Distribution \& Logistic Management 33(3): 268-281.

Lankenau, M.C.; Wehmeyer, K.; and Klein, S. 2005. Multi-Channel Strategies: Capturing and Exploring Diversity in the European Retail Grocery Industry. International Journal of Electronic Commerce, 10 (2): 85-122.

Lawrence, T. B., and N. Phillips. 2004. From Moby Dick to Free Willy: Macro-cultural discourse and institutional entrepreneurship in emerging institutional fields. Organization, 11(5): 689-711.

Macaulay, L.A.; Keeling, K.; McGoldrick, P.; Dafoulas, G.; Kalaitzakis, E.; and Keeling, D. 2007. Co-evolving E-tail and On-Line Communities: Conceptual Framework. International Journal of Electronic Commerce, 11 (4) (Summer): 53-77.

Murphy, A.J. 2007. Grounding the Virtual: The material effects of electronic shopping. Geoforum, 38: 941-953.

Nagy, G., \& Salhi, S. 2005. Heuristic algorithms for single and multiple depot vehicle routing problems with pickups and deliveries. European Journal of Operational Research, $162,126-141$.

Nagy, G., \& Salhi, S. 2007. Location-routing: Issues, models and methods. European Journal of Operational Research, 177, 649-672.

URL: http:/mc.manuscriptcentral.com/cjol Email: ijlra@informa.com 
Oh, L-B., and Teo, H-H. 2010. Consumer Value Co-creation in a Hybrid Commerce Service Delivery System. International Journal of Electronic Commerce, 14 (3) (Spring): 3562.

Oreg, S. 2006. Personality, context, and resistance to organizational change. European Journal Work and Organizational Psychology 15(1): 73-101.

Palmer, M.; Owen, M.; and De Kervenoael, R. 2010. Paths of the Least Resistance: Understanding How Motives Form In International Retail Joint Venturing. The Service Industries Journal, 30: 965-989

Park, C. H., and Y. G. Kim. 2003. Identifying key factors affecting consumer purchase behaviour in an online shopping context. International Journal of Retail and Distribution Management .31(1): 16-29.

Plank, R. E.; Reid, D. A.; and Pullins, E. B. 1999. Perceived trust in business-to- business sales: A new measure. Journal of Personal Selling and Sales Management, 19 (3): 6171.

Parragh, S. N., Doerner, K. F., \& Hartl, R. F. 2008. A survey on pickup and delivery problems, partI: Transportation between customers and depot. Journal für Betriebswirtschaft, 58(1), 21-51.

Parragh, S. N., Doerner, K. F., \& Hartl, R. F. 2008. A survey on pickup and delivery problems, part II: Transportation between pickup and delivery locations. Journal für Betriebswirtschaft, 58(2), 81-117.

Prasarnphanich, P., and Gillenson. M.L. 2003. The hybrid clicks and bricks business model. Communications of the ACM, 46 (12): 178-185.

Punakivi, M., and K. Tanskanen. 2002. Increasing the cost efficiency of e-fulfillment using shared reception boxes. International Journal of Retail and Distribution Management 30: 498-507. 
PWC, 2012. Intersections: Transportation and logistics industry merger and acquisitions" http://www.pwc.com/us/en/industrial-products/publications/intersections.jhtml Accessed December 2012.

Ramus, K., and Nielsen, A. 2005. "Online grocery retailing: what do consumers think?", Internet Research, 15 (3): 335 - 352.

Rheingold, H. 2002. Smart mobs. The next social revolution. MA, USA: Perseus Publishing.

Richey Jr., R.G.; Tokman, M.; and Skinner L.R. 2008. Exploring collaborative technology utilization in retailer-supplier performance. Journal of Business Research, 61: 841849.

Rohm, A. J. and V. Swaminathan. 2004. A typology of online shoppers based on shopping motivations. Journal of Business Research .57: 748-757.

Rotem-Mindali, O. 2010. E-tail versus retail: The effects on shopping related travel empirical evidence from Israel. Transport Policy, 17: 312-322.

Saeed, K.A.; Grover, V.; and Hwang, Y.2003. Creating synergy with a clicks and mortar approach. Communications of the ACM, 46 (12): 206-212.

Sanchez, J. A., Vijande, M. L., and J.A. Gutierrez. 2010. The impact of relational variables on value creation in buyer-seller business relationships. Journal of Business-to-Business Marketing 17: 62-94.

Shih, H.P. 2004. An empirical study on predicting user acceptance of e-shopping on the web, Information \& Management, 41: 351-368.

Silverstein, M. J., and N. Fiske. 2005. Trading up: Why consumers want new luxury goods, and how companies create them. (rev. ed.), New York: Portfolio.

Swidler, A.1986. Culture and Action: Symbols and Strategies. Amer. Sociol. Rev. 51(2), pp. 273-286. 
Tsou, H-T. 2012. The effect of interfirm codevelopment competency on the innovation of the e-service process and product: the perspective of internal/external technology integration mechanisms. Technology Analysis and Strategic Management, 24(7): 631646.

Tungate, M. 2004. Fashion Brands: Branding Style from Armani to Zara. London: Kogan Page.

Ugurlu, S., Bozkaya, B., and R. de Kervenoael. 2013. A New VRPPD Model and a Hybrid Heuristic Solution Approach for ETailing. European Journal of Operational Research (Forthcoming).

Venkatesh, V.; Morris, M.G.; Davis, G.B.; and Davis, F.D. 2003. User acceptance of information technology: Toward a unified view. MIS Quarterly, 27: 425-478.

von Hippel, E. 2005. Democratizing Innovation. Cambridge, MA, MIT Press.

Vroom, H. V. 1964. Work and Motivation, John Wiley\&Sons Inc. USA.

Vroom, V. 1964. On the Origin of the Expectancy Theory. In K. G. Smith and M. A. Hitt (Eds.), Great Minds in Management UK: Oxford University Press, (2005), 239-259. 
FIGURE 1

A MODEL OF CONSUMERS' EXPECTATIONS FOR ONLINE RETAIL PROVISION

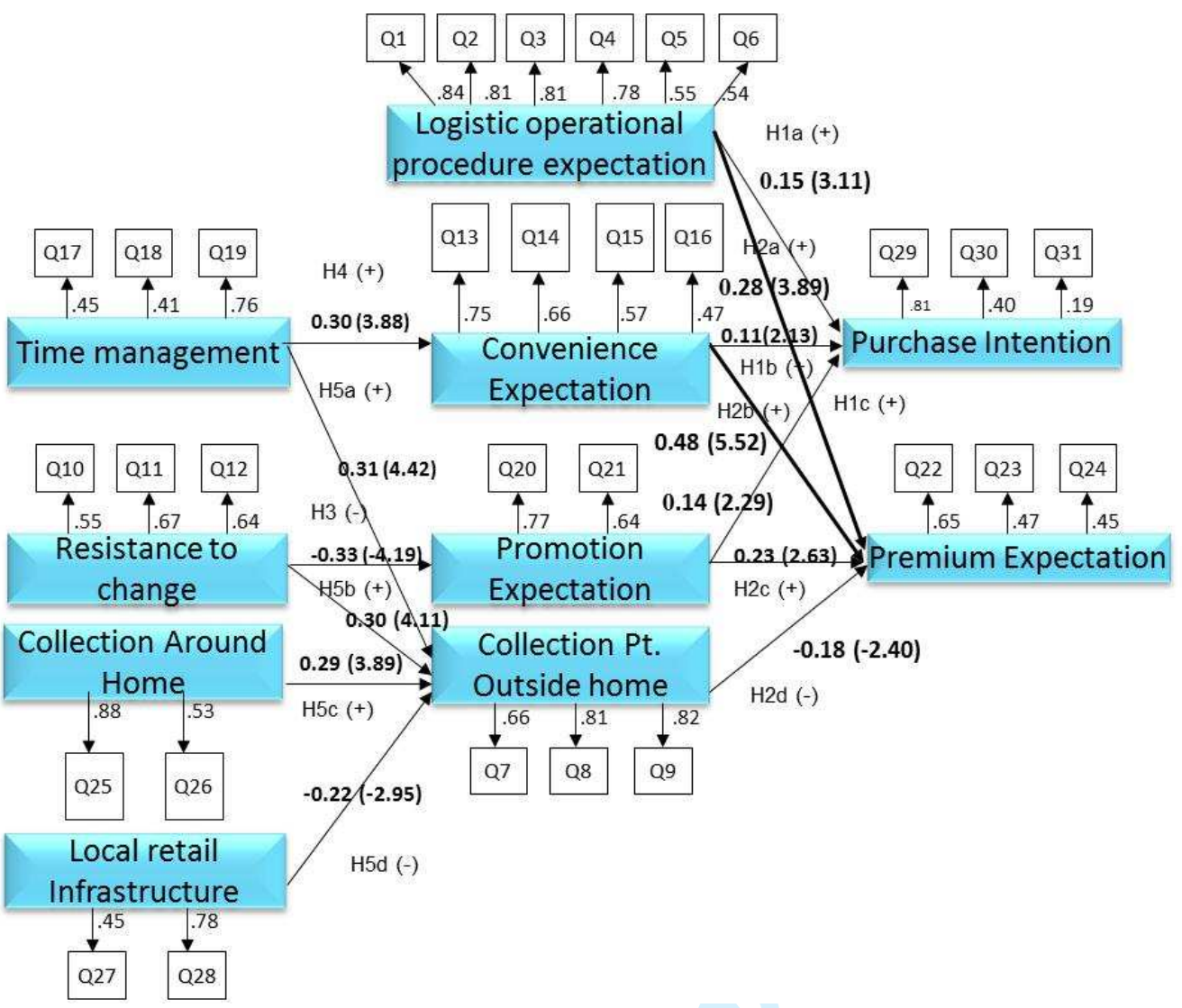

URL: http:/mc.manuscriptcentral.com/cjol Email: ijlra@informa.com 
Table 1: SCALE ITEMS FOR ONLINE GROCERY CHOICE

\begin{tabular}{|c|c|}
\hline Name & Constructs \\
\hline \multirow{6}{*}{$\begin{array}{l}\text { Logistic } \\
\text { Operational } \\
\text { Procedure } \\
\text { Expectation }\end{array}$} & I think cleanness of online logistic delivery services (van) is a problem. \\
\hline & I think the cold chain in logistic delivery vehicles is a problem. \\
\hline & I think cleanness of online grocery logistic delivery personnel is a problem. \\
\hline & I think the hot weather is a problem in Turkey for logistic grocery delivery. \\
\hline & $\begin{array}{l}\text { During my online grocery purchases, I am worried about the logistical security } \\
\text { of the financial transactions on the web and at the door via wireless POS. }\end{array}$ \\
\hline & $\begin{array}{l}\text { I am scared that my online grocery order will be tampered with during } \\
\text { transport. }\end{array}$ \\
\hline \multirow{3}{*}{$\begin{array}{l}\text { Collection Points } \\
\text { Outside Home }\end{array}$} & I would like special delivery boxes to be made available in/around my office. \\
\hline & I would like special collection boxes to be made available on the main roads. \\
\hline & $\begin{array}{l}\text { I would like special delivery boxes to be made on the main public transport } \\
\text { transit points. }\end{array}$ \\
\hline \multirow{4}{*}{$\begin{array}{l}\text { Resistance to } \\
\text { Change }\end{array}$} & $\begin{array}{l}\text { It would make little logistic difference to me if I had to stop shopping for } \\
\text { online grocery. }\end{array}$ \\
\hline & $\begin{array}{l}\text { To change my preference from store shopping to online shopping would } \\
\text { require major logistical rethinking. }\end{array}$ \\
\hline & I consider myself to be highly loyal to offline shopping. \\
\hline & $\begin{array}{l}\text { The convenience of local shops -free buses, delivery- is worth the extra it can } \\
\text { cost. }\end{array}$ \\
\hline \multirow{4}{*}{$\begin{array}{l}\text { Convenience } \\
\text { Expectation }\end{array}$} & Shopping online for groceries makes my life easier. \\
\hline & I shop for online grocery because I don't like to carry heavy bags. \\
\hline & Shopping online for groceries is an efficient way to manage my time. \\
\hline & $\begin{array}{l}\text { I prefer shopping online for groceries because it does not require a lot of } \\
\text { physical effort. }\end{array}$ \\
\hline \multirow{3}{*}{$\begin{array}{l}\text { Time } \\
\text { Management }\end{array}$} & I find shopping for my groceries very tiring. \\
\hline & I would prefer doing all my shopping just once a week. \\
\hline & I try to avoid walking for more than five minutes with my shopping. \\
\hline \multirow{2}{*}{$\begin{array}{l}\text { Promotion } \\
\text { Expectation }\end{array}$} & $\begin{array}{l}\text { I will shop more for online groceries if the retailers offer more free samples } \\
\text { test items and deliver free }\end{array}$ \\
\hline & $\begin{array}{l}\text { I will shop more for online groceries if the retailers propose special online } \\
\text { logistic promotions (free delivery to chosen location, office, home, others } \\
\text { points). }\end{array}$ \\
\hline \multirow{3}{*}{$\begin{array}{l}\text { Premium } \\
\text { Expectation }\end{array}$} & I would like to have online access to products that make me feel special. \\
\hline & I would like seasonal premium product. \\
\hline & $\begin{array}{l}\text { I would prefer to have online access to special international cuisine } \\
\text { ingredients. }\end{array}$ \\
\hline \multirow{2}{*}{$\begin{array}{l}\text { Collection Around } \\
\text { Home }\end{array}$} & $\begin{array}{l}\text { I would like the option for my online grocery orders to be delivered to my } \\
\text { home security/porter. }\end{array}$ \\
\hline & $\begin{array}{l}\text { I would prefer if my online grocery orders are given to my neighbor when I am } \\
\text { not at home. }\end{array}$ \\
\hline \multirow[t]{2}{*}{$\begin{array}{l}\text { Local Retail } \\
\text { Infrastructure }\end{array}$} & $\begin{array}{l}\text { There are already plenty of local food stores that deliver to choose from in this } \\
\text { area. }\end{array}$ \\
\hline & I can easily get to any food store I wish in my local area. \\
\hline
\end{tabular}


Table 3. Results of the SEM

\begin{tabular}{|c|c|c|c|}
\hline Hypotheses & Path & Path Value & Result \\
\hline Hypothesis 1 & $\begin{array}{ll}\text { Logistics Org. Pr. Exp. } \rightarrow \text { Purchase Intention } \\
\text { Convenience Exp. } & \rightarrow \text { Purchase Intention } \\
\text { Logistics Prom. Exp. } & \rightarrow \text { Purchase Intention }\end{array}$ & $\begin{array}{l}.15^{* * *} \\
.11^{* *} \\
.14^{* *}\end{array}$ & Supported \\
\hline Hypothesis 2 & $\begin{array}{ll}\text { Logistics Org. Pr. Exp. } \rightarrow \text { Premium Exp. } \\
\text { Convenience Exp. } & \rightarrow \text { Premium Exp. } \\
\text { Logistics Prom. Exp } & \rightarrow \text { Premium Exp. } \\
\text { Collection Pt. Out. H. } & \rightarrow \text { Premium Exp. }\end{array}$ & $\begin{array}{l}.28^{* * *} \\
.48^{* * *} \\
.23^{* *} \\
-.18^{* *}\end{array}$ & Supported \\
\hline Hypothesis 3 & Resist. to change $\quad \rightarrow$ Logistics Prom. Exp. & $.33^{* \star *}$ & Supported \\
\hline Hypothesis 4 & Time management $\rightarrow$ Convenience Exp. & $.30^{* * *}$ & Partially supported \\
\hline Hypothesis 5 & $\begin{array}{l}\text { Time management } \rightarrow \text { Collection Pt. Out. H. } \\
\text { Resist. to change } \rightarrow \text { Collection Pt. Out. H. } \\
\text { Collect. Pt. Ar. H. } \rightarrow \text { Collection Pt. Out. H. } \\
\text { Local Retail Infr. } \rightarrow \text { Collection Pt. Out. H. }\end{array}$ & $\begin{array}{l}.31^{* * *} \\
.30^{* * *} \\
.03^{* * *} \\
-.22^{* *}\end{array}$ & \\
\hline Fit measures & Endogenous constructs & Main model & \\
\hline$R^{2}$ & $\begin{array}{l}\text { Collection Pt. Out. H } \\
\text { Convenience Exp. } \\
\text { Logistics Prom. Exp. } \\
\text { Premium Exp. } \\
\text { Purchase Intention }\end{array}$ & $\begin{array}{l}.40 \\
.09 \\
.11 \\
.39 \\
.08\end{array}$ & \\
\hline
\end{tabular}


Table 2. Correlations Reliability and Descriptive Statistics

\begin{tabular}{|c|c|c|c|c|c|c|c|c|c|c|c|c|c|}
\hline Mean & S.Dev & & Variables & 1 & 2 & 3 & 4 & 5 & 6 & 7 & 8 & 9 & 10 \\
\hline 2.84 & 0.99 & 1 & $\begin{array}{l}\text { Logistics Opr. } \\
\text { Pr. Exp. }\end{array}$ & (.73) & & & & & & & & & \\
\hline 2.89 & 1.09 & 2 & $\begin{array}{l}\text { Collection pt. } \\
\text { Outside }\end{array}$ & -.03 & (.77) & & & & & & & & \\
\hline 3.05 & 0.90 & 3 & $\begin{array}{l}\text { Resistance to } \\
\text { Change }\end{array}$ & $.14^{* * *}$ & $.30^{* * *}$ & $(.61)$ & & & & & & & \\
\hline 4.20 & 0.57 & 4 & $\begin{array}{l}\text { Convenience } \\
\text { Expectation }\end{array}$ & $.18^{* * *}$ & -.003 & $.20^{* * *}$ & $(.62)$ & & & & & & \\
\hline 3.42 & 0.90 & 5 & $\begin{array}{l}\text { Time } \\
\text { Management } \\
\text { Logistics }\end{array}$ & .09 & $.23^{* * *}$ & .07 & $.20^{* * *}$ & $(.55)$ & & & & & \\
\hline 4.00 & 0.78 & 6 & $\begin{array}{l}\text { Promotion } \\
\text { Exp. }\end{array}$ & -.05 & $.09^{*}$ & $.19^{* * *}$ & $.17^{* * * *}$ & .02 & $(.72)$ & & & & \\
\hline 3.86 & 0.70 & 7 & $\begin{array}{l}\text { Premium } \\
\text { Expectation }\end{array}$ & $.15^{* * *}$ & $-.13^{* *}$ & $.16^{* * *}$ & $.28^{* * *}$ & .04 & $.18^{* * *}$ & $(.53)$ & & & \\
\hline 2.93 & 1.07 & 8 & $\begin{array}{l}\text { Collection pt. } \\
\text { around Home }\end{array}$ & -.08 & $.37^{* * *}$ & $.16^{* * *}$ & .05 & .05 & $-.10^{*}$ & $.08^{* * *}$ & (.69) & & \\
\hline 3.89 & 0.83 & 9 & $\begin{array}{l}\text { Local Retail } \\
\text { Infrastructure }\end{array}$ & .07 & $.20^{* * *}$ & .01 & $.11^{* *}$ & $.05^{* * *}$ & .08 & $.15^{* * *}$ & $.09^{*}$ & $(.60)$ & \\
\hline \multirow[t]{4}{*}{2.07} & 0.96 & 10 & $\begin{array}{l}\text { Purchase } \\
\text { Intention }\end{array}$ & $.13^{* *}$ & -.01 & $.29^{* * *}$ & .04 & .09 & $.12^{* *}$ & .01 & -.02 & -.07 & $(.74)$ \\
\hline & & & $\begin{array}{l}\text { Composite } \\
\text { reliability }\end{array}$ & .87 & .81 & .70 & .71 & .57 & .87 & .53 & .69 & .52 & .70 \\
\hline & & & Cronbach's $\alpha$ & .87 & .80 & .70 & .71 & .57 & .67 & .52 & .63 & .52 & .66 \\
\hline & & & AVE & .54 & .59 & .37 & .39 & .31 & .52 & .28 & .45 & .35 & .55 \\
\hline
\end{tabular}




\title{
Trading-up on Unmet Expectations?
}

\section{Evaluating consumers' expectations in online premium grocery shopping logistics}

\begin{abstract}
Geography and retail store locations are inherently bound together; this study links food retail changes to systemic logistics changes in an emerging market. The later include raising income and education, access to a wide range of technologies, traffic and transport difficulties, lagging retail provision, changing family structure and roles, as well as changing food culture and taste. The study incorporates demand for premium products defined by Kapferer and Bastien, (2009b) as comprising a broad variety of higher quality and unique or distinctive products and brands including in grocery organic ranges, healthy options, allergy free selections, and international and gourmet/specialty products through an online grocery model $(n=356)$ that integrates a novel view of home delivery (HD) in Istanbul. More importantly from a logistic perspective our model incorporates any products from any online vendors broadening the range beyond listed items found in any traditional online supermarkets. Data collected via phone survey and analysed via structural equation modelling (SEM) suggest that the offer of online premium products significantly affects consumers' delivery logistics expectations. We discuss logistics operations and business management implications, identifying the emerging geography of logistic models which respond to consumers' unmet expectations using multiple sourcing and consolidation points.
\end{abstract}

Key words: emergent markets, logistics, premium products, e-shopping, retail geography.

\section{1- Introduction}


Logistics forms a significant dimension in retailing, yet much of what we know about retail spatial behaviour is centred on fixed-unit food stores. Increasingly, however, retailing is bound by, and interconnected with, rapidly changing local geography and consumption practices. The logistics associated with traditional bricks and mortar stores may struggle to meet consumers' trading-up expectations while at the same time, new styles - and locations of dwellings are even challenging online retail business operating models. While there can be little doubt that technological revolutions in communications have eliminated some of the constraints of place-based retailing and re-defined distance, little is known of the consumer trading-up expectations in emerging large metropolises. The trading-up cycle of expectations is at the heart of the 'Wheel of Retailing' theory (Hollander, 1960), which is based on the notion that organizations commence as low cost/low price businesses, but that as the business develops so it 'trades up' and adds services, ambience and other more expensive attributes, reflecting consumers' increasing expectations. Expectation has been defined as a state of expecting or looking forward to an event as about to happen (Vroom, 1964). Expectations play an important role in determining the direction of urban, technological and social change and the rate at which brand, retail and logistic innovations are adopted (Nagy and Salhi, 2005, 2007; Braysy and Gendreau, 2005a, 2005b).

Nonetheless, a growing concern exists that current operational practices do not adequately reflect the expectations associated with the micro socio-spatial changes in the urban environment of most post- 1990s cities in emerging markets. The vibrant nature of these emerging market ecosystems is a theoretically and empirically rich domain; the development of metropolises such as Istanbul is at what Bouzarovski, Salukvadze, and Gentile, (2010) termed "a developmental breakout phase" and requires ever more innovative logistic strategies to create mechanisms that cope with increased dwelling densities, traffic, associated 
pollution and post-consumption waste management. In these markets, retailers are facing dynamic environmental conditions affected by new, more informed consumers via a rapid penetration and usage of the Internet often via mobile devices (Deloitte, 2010). Meanwhile, the food industry is far more concentrated than 20 years ago; the latest technologies are implemented by some, resulting in leapfrogging of traditional supply chain management practices (PWC, 2012). Yet, despite - or perhaps because of - a rather opaque form of urban planning and retail infrastructure development, often emerging after the creation of initial settlements and dwellings (Punakivi and Tanskanen, 2002), the remits of the main actors, namely online retailers, logistics firms and urban planners, are now converging and increasingly interconnected, calling for the development of new conceptualisation of e-service logistic management. The above problem settings can be recognized as variants of the wellknown vehicle routing problem, which is studied extensively in the operations research and management science literature. Variants of the problem include the cases with or without delivery time windows, vehicle capacities, deterministic or stochastic order locations, split deliveries, and simultaneous pick-up and delivery among many others. We refer the interested reader to the surveys by Nagy and Salhi (2005, 2007), Parragh et al (2008a, 2008b) and Braysy and Gendreau (2005a, 2005b).

Under these dynamic conditions, a knowledge gap exists in the retail technology analysis and strategic logistics management literature regarding the expectations associated with the development of online retail firms' logistics operations (Tsou, 2012; Kotzab and Teller, 2003). Such a gap must take into account (i) demand-led changes in emerging market condition (counter-intuitively often leading to the need for premium products to be made available), (ii) a loose legal environment, and (iii) socio-spatial changes in the built environment of most post 1990s cities (Cheema and Papatla, 2010). Traditional bricks and 
click stores may struggle to meet consumers' expectations of brands. According to Kapferer and Bastien (2009a), brands are catalogued along a top-down scale ranging from (a) luxury products and brands (centred on prestige e.g. Hermes), (b) Masstige brands taken as massproduced, relatively inexpensive goods which are marketed as luxurious or prestigious (e.g. Starbucks, and Zara), (c) Premium brands (e.g. Hyatt, Kroger, Tesco Finest, Cadbury) to (d) Medium level brands (Tesco Budget) (Silverstein and Fiske 2003; Keller 2009). Brands vary along a continuum in their main constitutive characteristics including price, quality, rarity, extra-ordinariness, aesthetics and symbolism. As such, premium brands have to remain pragmatic regarding their value-for-money ratio. Both the trading-up strategy of masstige and premium brands and the trading-down strategy of luxury brands make luxury-like products accessible for middle-class consumers (democratization of luxury) (Tungate, 2004). Democratic luxury products are characterized by Kapferer and Bastien (2009b, p. 314) as "ordinary items for extraordinary people, which are at the same time extraordinary items for ordinary people".

Grocery retailers use premiums to attract and retain consumers who would not normally buy a product or service on this occasion or only the lower priced equivalent from third party brands (private labels). As such, premiums are used to introduce new products, provide extra appeal in special sales events, meet competitive prices, provide copy appeal, and promote larger size units. They used premium brands to boost sales hence basket size and overall profitability. In particular, premium offerings are "including not just higher quality and unique or distinctive items, but also natural and organic, better-for-you and international and gourmet/specialty products" (Kapferer and Bastien, 2009b). Taken together, a Premium brand is a brand that holds a unique value within a specific market and or a particular audience (e.g. SAAB, Tesco finest Belgian chocolate salted caramel \& hazelnut ice cream). Grocery retailers also purse their premium positioning through accreditations (e.g. Fairtrade, Free range, outdoor bred, 
and Linking Environment And Farming scheme (LEAF)), demonstrating their lack of compromise on quality standards or sourcing integrity to consumers compromise (de Kervenoael et al, 2011).

In our case, premium products (sourced from multiple- online- vendors, i.e. beyond listed items found in any supermarket) carry specific expectations for logistics. First, the integrity of the packaging for transportation (e.g. chocolate items- not broken / cracked - as well as exterior visuals - the box's aesthetic that can be displayed for guests) is paramount, and storage temperature must be guaranteed. Second, extra care is expected during handling and mixing with other items in the shopping cart (compression and leakages). Third, online, premium products will be searched for with great care-- including review of comparisons and feedbacks from other consumers, a process thus raising expectations (no-substitutions) of consistency and quality. Fourth, an overall logistic premium service may also be expected from the type of delivery van (MINI, for example, launched the world's first premium compact delivery van for Urban-Hipster), courier (not driver) uniform, cleanliness and communication training to online tractability (stock level), clear paperwork (insurance), express delivery and return policy.

In this study, we examine the following question: under the conditions of an emerging market metropolis, can premium products through multi-sourced supply with a larger basket and consolidated flexible delivery lead to growth of online supermarkets sale? While much research in the retail grocery sector has emphasized technology-led supply resource planning, comparatively little is known about how consumers' expectations - shaped by rapid social changes - have evolved. However, as Konrad's (2006) research highlights, expectations function as a coordination mechanism for customers and activities. For instance, positive 
expectations help to attract customers to emerging innovation systems and to align the interests and activities of these actors. Moreover, the practice of alignment and coordination can create legitimacy for the new logistics initiative, retail brand and technology. Expectations are therefore important in shaping operational performance potentials and are attributed to defining the global marketplace opportunities. Motivation and risk where a reasonable benefit or performance is foreseen drive expectations (Elliot and Fowell, 2000).

Consumer expectations are trading-up and stretching the capacity of the online retail business operating models. Two operational models dominate the market - in-store picking and the distribution centre. Some extant studies have questioned whether or not both models are operationally ill-equipped, individually, to account for the changing demography, growing choice and increasing expectations for the provision of premium offerings (Hays and Keskinocak, 2004). Premium offerings are "including not just higher quality and unique or distinctive items, but also natural and organic, better-for-you and international and gourmet/specialty products" (Kapferer and Bastien, 2009). The nature of these premium offerings, along with the operational limitations of the traditional online grocery models, has resulted in a new hybridization operational model emerging in practice (Kim et al., 2010). Hybrid models involve multiple sourcing actors, order consolidation points, and flexible collection points for consumers leveraging the complexity of the "final delivery mile" (Berman and Thelen, 2004; Gulati and Garino, 2000; Prasarnphanich and Gillenson, 2003; Saeed et al., 2003; Constantinides, 2004). In such settings, the perceived, unmet expectations of the consumer may predict online premium provision and operation management opportunities. In particular, we are also interested in how collective power, and uncoordinated and unmet expectations, can converge to shape new future practices that dynamically alter field-level retail logistics practices. 
The overall aim of the study is to present a theoretically justified research model encompassing both supply-led and demand-led attributes of online shopping behavior. This study extends research on identifying potential for hybrid online provision through multiple sourcing of premium products consolidated and delivered by users' current online supermarket, identifies the consumer expectations for online grocery premium provision, examines the supply and demand-led drivers of consumer expectations. We empirically demonstrate the significance of relationships between these factors using a sample of 356 online grocery consumers (i.e., regular online shoppers) in Istanbul.

The contribution of this study is threefold. First, in the logistics and distribution field, researchers have now begun to examine the demand-led processes by which consumers shape online provision amongst retail offers that provide hedonistic consumption, a scenario thus enabling simultaneous improvement in the economic performance of e-retail firms' strategy (Chen et al., 2007). This paper extends this work by including premium products not traditionally listed by supermarkets but sourced from elsewhere in the supply chain. Second, while much research has emphasized technology-led supply resource planning, comparatively little is known about how consumers' expectations shaped by changes in a socio-spatial environment may consequently alter online technology logistics provision. This study addresses this limitation. Following Ansari and Phillips (2011), we add to the understanding of the effects of crowd-sourcing by uncoordinated activities resulting in a critical mass and momentum so strong that the retail logistics practices at field-level are impacted. Third, although several dimensions developed in previous supply-led studies have touched on the logistic operational aspects emerging from developments within online provision, not one exclusively regards the potential impact for FMCGs as a basket of products.

The paper proceeds as follows. A brief survey of the theoretical and empirical literature on consumer choice in relation to the online grocery field is undertaken and exemplified by a 
synopsis of the logistical issues in Turkey and Istanbul. Research hypothesizes and methods demonstrate the usefulness of integrating premium products with advanced logistics.

\section{2- Conceptual underpinning}

A variety of studies have analyzed e-grocery models and behaviors: see for example Punakivi and Tanskanen (2002) and Agatz, et al., (2008) for a systematic review. This study summarizes the key aspects that specifically relate to the research objectives. In the operations and information field, researchers have recently started to pay greater attention to demand-led processes by which consumers co-evolve and shape online retail provision (Keen et al., 2004; Macaulay et al., 2007; Murphy, 2007). Expectations for new provision are impacting the nature and scale of online retail operations. In turn, expectation often links to motivation as "the explanation of choice made among different behaviors that are under central or voluntary control" (Vroom in Smith and Hitt, 2005, 247). In other words, once the channel is decided, what determines the direction and magnitude of shopping behavior, including the choices that are made among different providers and products available, is a result of expectations.

Historically, studies of online grocery provision draw on three distinct perspectives supply-led, demand-led and technology-enabled approaches. First, the supply-led operational research approaches encompass areas such as: collaborative models, including for example, material requirements planning (MRP), quick response $(\mathrm{QR})$, efficient consumer response (ECR), vendor managed inventory (VMI) and collaborative planning, forecasting and replenishment (CPFR); management operation strategies for consolidation leading to fulfillment cost savings, global pricing, global ICT standards, inventory and capacity information sharing; global efforts along the supply chain such as international sourcing to generate diversified order forecast, promotion and sale information sharing towards quality 
improvement and reduce "concept-to-market" product cycle time- all have implications for choice (Chen et al., 2007).

Within these studies, a general understanding emerges of a supply-led impact of choice on online grocery provision. Empirical studies show that grocery retail firms emphasize similarities and commonalities between store-based and online choice provision (Burt and Sparks, 2003). In effect, this analogy results in the dominance of in-store picking operational model. While alternative operational models exist, studies show that the economies of scale do not always support the full independent distribution center system for online provision (recall Web Van that failed in 2001) (Keen et al., 2004; Lankenau et al., 2006).

Regarding online provision, the strength of the traditional operations systems constrains grocery retailers; that is, meeting local store-based competitive pressures forces the centralization of administrative processes, standardization and the uniformity of provision that precludes wider non-listed multi-sourcing partners. Based on operational advantage (i.e., size and dominance), grocery retailers selectively increase provision, but in doing so, business operating models often reduce varieties of localness. Empirically, the limited and relatively small provision that individual online retailers operationally deploy in practice creates a system that encourages a highly limited number of large approved standardized sourcing suppliers. Online, in the case of a basket of often low priced goods such as groceries, a wider choice being a click away (i.e., going to other e-retailers in the middle of the shopping experience) is not common practice (Hsiao, 2009). For consumers, this practice means that once inside an online retailer site, a captive provision-set exists. This type of supply-led controlled provision greatly increases retailers' buying power and concentration in the industry (Competition Commission, 2008). From this perspective, choice provision is a measure of operational supply-based performance. 
The supply chain literature examines a range of operational choice models ranging from brick and click, pure play to third party logistics (Murphy, 2007). In that literature, provision represents the awareness and capability of retail firms to identify the total supply provision accessible. At one level, expectations revolve towards a simple updated list: who can collaborate in supplying provision range? These inquiries evaluate the various trading partners and channels available ranging from take-away restaurants, markets, forecourts, farm shops, grocery stores and other trading partners.

A second, demand-led explanation of online grocery provision emerges. This literature finds that consumers' expectations form the "real" choice between and within channels, stores and brands (Chen et al., 2007; Clarke, 2000). Indeed, nowadays, online consumers increasingly question the lack of divergence between store-based and online provision. Studies show that online retailers have operationally responded in different ways. Measures include, but are not limited to, offering unique multimedia and often interactive consumer experience (image differentiation), listing novelty and limited edition not available offline (limited customization), responding quickly to demand for specific information (one to one relationship with current and potential consumers) (Keen et al., 2004; Macaulay et al., 2007). In effect, online consumer demands increase the operational complexities from the heterogeneity in the provision of goods (e.g., premium offerings), while at the same time, challenging routinized operational models that are efficient and effective.

In contrast to the supply and demand-led approaches, a final approach, a technologyenabled explanation, bears directly on the issue of online grocery provision (Burt and Sparks, 2003; Ramus and Nielsen, 2005). This technology-enabled explanation attributes greater transparency over online grocery provision. In this regard, the literature highlights two challenges associated with provision: a restricted range with compatible standards (i.e., ready 
to accept contractual terms), technologies, and an operation model based on volume that excludes multiple smaller sources of supply. Studies such as Elliot and Fowell (2000), Shih (2004), and Constantinides (2004) point to the role of both standardization and future IT investment, and global legislation and regulatory concerns (e.g., privacy concern regarding radio frequency ID, global positioning system and geographic information system usage) in relation to collaboration. Therefore, although the results of early studies on the role of technology-enabling seemed promising, recent studies conclude that evidence of the hypothesized effect of IT on provision is weak at best.

Two observations emerge from the three literatures. First, the supply side studies note that firms must secure competitiveness and gain market legitimacy from product differentiation, while simultaneously having a similar product provision, to meet consumer expectations. However, little attention exists towards consumers' unmet expectations; that is to say, the difference between initial expectations (or needs) and actual experiences on the online grocery provision. Studies have pointed to the ways that online retailers resist widening access towards low volume provision to maintain operational efficiencies. While retailers use “cross-docking" processes, whereby suppliers aggregate bulk broken pallets and label them according to their destination store, thus leading to the direct re-routing of goods to the appropriate transport without leaving the distribution center loading bay, these processes significantly differ from consolidation points that involve an individual consumer ordered basket, permitting multi-store sourcing depending on stock level, and multi-providers' sourcing through non-listed partners aggregated within a single fulfillment operation.

Second, the literature does not discriminate provision "between and within" online retailers as a unit of analysis for study. Studies mostly discriminate between discretionary operational sourcing power among many products and providers or on the effects of consolidating the sourcing operation. Understanding this nuance plays an important role in the 
subsequent analysis designed to evaluate the expectation for premium product provision the online grocery market. Traditional operational models may result in consumers experiencing less of desire rather than anticipation (i.e., unmet expectations).

Significantly, though, premium products have specific attributes that may encourage regular provision volume as an important aspect towards operational viability. In other words, "when consumers have tasted luxury [premium in this case] in whatever they are, it is very difficult for them to turn away from it" (Kapferer and Bastien, 2009, 16). Premium, upper range, mass luxury, super premium, opulux, masstige and trading up raise prices and subsequently operational margins. This type of provision opens new growth opportunities for online retailers including a new set of relatively wealthy buyers, young and eager to create the powerful impressions that demonstrate access to the world of premium products. Increasing the provision of premium products, offers accessibility to completely new innovations, to new cultures, emotions and desires all raising the online retailers' brand image. This argument is commensurate with the FMCG product practice (e.g., L'Oreal, P\&G) that aspires to be a “true premium" for everyone (Silverstein and Fiske 2005).

\section{From traditional logistic relevance to emerging market e-strategy models: Turkey}

We now turn to our case study where powerful retailers may be missing the rise of substantial purchaser power of an emergent market. Structurally, however, though emergent markets may be inherently receptive to e-grocery per se, it does not follow that standard operating models can merely be imported. Western e-grocery models are primarily based on in-store picking or distribution centres. However, as with click and collect, the former implies the existence of a suitable store chain network; the latter, costly new-build. More suited to Istanbul might be a system involving multiple sourcing actors but, with ideally, a single 
payment made for all goods. Spatially, order consolidation points leading to a single delivery, and/or flexible collection points within a set of possible delivery locations (as used by courier services such as UPS or FedEX), might maximize consumers' expectations of convenience and thus reduce operational duplication.

Istanbul, Europe's largest city, demonstrates how the retail system may be required to modify its approach to meet the aspirations of a rising dispersed global middle class (Eraydın, 2011). One currently very high profile and relevant spatial aspect is the privatization of public spaces - malls - and the creation of secured 'gated communities' within the city. This phenomenon sits alongside a rather opaque form of urban planning and retail infrastructure development, often emerging long after the creation of initial settlements and dwellings (Punakivi and Tanskanen, 2002). Rising incomes, multiply-sourced premium products, and consolidated flexible home delivery ought to lead to the growth of online supermarket sales. Products could include premium products not traditionally listed by supermarkets but sourced elsewhere in the supply chain (the Amazon affiliate marketing principle). This resonates with the macro-economic fact that, as of 2011, Turkey's GDP per capita is about twice that of China and its growth rate in 2011 is second to China (Deloitte, 2010). According to Planet Retail, the turnover of the retail sector in Turkey in 2006 was $\$ 136.9$ billion rising by 2010 to $\$ 199$ billion. Numerically, the retail sector is, however, still dominated by a large number of small, independent, and single-location retailers. Capital accumulation is undersized, technologies used by retailers and business organizations are small-scale and most products and services are basic. Only in 1987 were the first two large supermarket brands established: Migros and Gima. In Istanbul, the first hypermarket, cash and carry Metro, opened in 1988. Despite the rapid development of modern retail formats, including hard discounters, supermarkets' share remains well below the $25 \%$ taken in most European markets. Alongside these trends, on the consumer side, since 2000 a tremendous growth in Internet usage 
$(+700 \%)$ and a rapid increase in online shopping activity have occurred. According to the Interbank Card Centre, in 2008, online transactions were already of $\$ 1.2$ billion with a projected increase to $\$ 2.2$ billion by the end of 2012 . Half of the 35 million consumers use the Internet for shopping (Aydemir, 2010).

To respond to this rapidly evolving environment, goods might best be supplied by vendors/suppliers from multiple locations in the supply network but delivered to each customer's designated delivery address as a consolidated order (Yanik et al., 2014). Any store could be the locus of such provision. The development of collection and delivery points (CDPs), either unattended in the form of locker points (e.g. shared reception box concept) or attended service points (e.g. gated community entrances), would generate cost savings (e.g. mileage, capacity utilization) and possibly more linked shopping. Here, the importance to emerging markets of gated communities with security and ground services lies in how this reality can be leveraged. Thus, multiple trucks/ fleets may synchronize their movements to complete the basket of items on a customer's shopping list. These trucks will then meet at "transfer points" also regarded as collection and delivery points (CDPs) to consolidate items from multiple vendors. These problem settings can be recognized as variants of the wellknown vehicle routing problem. We refer the interested reader to Yanik et al., (2014) and Daugherty (2011) as the details of these problems and the associated models extend beyond the scope of this paper.

\section{Research model and hypotheses}

This paper's research model draws together constructs from demand-led models (Clarke et al., 2006) and supply-led models (Collier and Bienstock, 2006b; Oh and Teo, 2010; Richey et al., 2008; Rotem-Mindali, 2010). Traditional constructs include time management, convenience, resistance to change, promotion, operational procedures, and collection around and outside the home. The model in this study also includes the novelty of premium products 
(Kapferer and Bastien, 2009; Silverstein and Fiske, 2005) and an attribute to control for overall local retail infrastructure impact.

This study defines online provision as the business management integration of organizational procedure, convenience, promotion, time management, resistance to change, local retail infrastructure, collection points, and premium expectation that create market opportunities enabling online shopping and the realization of online consumers' purchase intention. Based upon the literature, the following sub-sections describe constructs' definition and related hypotheses. Figure 1 presents the conceptual model to be tested.

Insert Figure 1 about here: A MODEL OF CONSUMERS' EXPECTATIONS FOR ONLINE RETAIL PROVISION DELIVERY

\section{(1) Intentions for Online Grocery Purchases}

On the supply side, retail grocery competition has intensified with the emergence of online provision and transnational retail firms, creating higher, often dispersed, purchase expectations (Ha and Stoel, 2009). At the same time, increasing economic prosperity has commensurately increased consumers' expectations for hedonistic online provision on the demand side. Both theory and empirical support exists between intention to engage in behavior and actual behavior. In accordance with existing studies, the study uses behavior. In delivering online grocery, operationally the provision must be complicit with operational procedure requirements (e.g., cleanliness, refrigeration for chilled and frozen goods). Thus, retail firms' operational procedures for provision must meet strict handling requirements as part of consumers' expectations. Retailers that respond or already demonstrate a high level of operational procedure development can expect consumers to integrate even greater expectations of operational procedure progress in their intention to make further purchases. Consumers relate fulfillment of future expectations with their future intention to purchase, 
encouraging retailers to adopt a balanced approach to relationship building intention as a surrogate for actual behavior (Park and Kim, 2003; Constantinides, 2004). From our considerations, we devise the following hypotheses:

H1a: The higher the consumers' expectations for online operational procedures, the greater the intention to purchase.

Expectation for convenience is another determinant of online grocery provision. Convenience includes distance and access, physical capabilities, time management and frequency, and integration with other commitments (Jackson et al., 2006; Rohm and Swaminathan, 2004; Oh and Teo, 2010). Thus, retail firms' operational provision must be cognizant of online consumers' expectations for convenience.

H1b: The higher the consumers' expectations for convenience, the greater the intention to purchase.

Empirical models show support for consumer bipolarization in online environments not only a negative customer reaction to dual pricing appears but support for expanding the operational provision of the online value proposition is also present. That is, while online promotions are traditionally enhancing the perception of price and quality (Darke and Chung, 2005), the provision of promotions including but not limited to, free samples, tailored packaging, bonus packs, and unique online complimentary offers, often strongly determine online grocery provision (Close and Kukar-Kinney, 2010; Rohm and Swaminathan, 2004). Thus retail firms' operations must be congruent with online consumers' expectations for exclusive promotions.

H1c: The higher the consumers' expectations for promotion, the greater the intention to purchase.

(2) Expectations for Premium Offers 
Consumers' expectations calculate the utility as well as meaning, and logistics operations essentially facilitate the provision of both, especially in the premium market. Unlike price offers, however, premium purchases involve greater fulfilment costs and risks regarding online logistic operational procedure provision (Collier and Bienstock, 2006). Subsequently, the expected convenience of the logistic provision comprises the efficient and timely delivery of online goods (Rohm and Swaminathan, 2004). Furthermore, good logistics - especially if driven by exclusive online promotions (e.g. free shipping, secure/special shipping and delivery timing upgrades) are a key determinant of online consumers' expectations (Silverstein and Fiske, 2005). Lastly, the literature contends that operating a set of collection points across multiple locations is essential to the online provision (Punakivi and Tanskanen, 2002). Therefore, we suggest the following four hypotheses:

H2a: The higher the consumers' expectations for online grocer's logistic operational procedure provision, the greater the expectation of premium offers.

H2b: The higher the consumers' expectations for online logistic convenience provision, the greater the premium expectation.

D2c: The higher the consumers' expectations for online logistic promotion provision, the higher the premium expectation.

The literature contends that operating a set of collection points across multiple locations is an integral part of the online provision (Punakivi and Tanskanen, 2002). Theoretical and empirical studies identify three operational models of collection: home collection, store pickup and at an unmanned, secure drop box. Studies show that these approaches are operationally well-equipped, collectively, to account for non-premium product offerings; however, this study hypothesizes that such models may be ill-equipped for the increasing consumers' expectations for premium offering provision (Agatz et al., 2008; Kamarainen and Tanskanen, 2001). Premium provision management models that do not guarantee the integrity of the 
goods at the final destination, that do not signal positive impression cues at the manned points of collection, and that do not attach a social meaning to the operation are less likely to meet online consumers' expectations. A negative relationship is expected, towards alternative collection points as they do not allow control of the premium goods by consumers

H2d: The lower the consumers' expectations for online unmanned collection points' provision, the greater the premium offer expectation.

\section{(3) Expectations for Online Promotions}

Resistance to change is a long established idea in the technology acceptance literature (Venkatesh et al., 2003). Adopting habitual patterns of behaviors is an important determinant of exclusive online promotion provision. Although promotion provision opportunities are common in retail operation environments (Burt and Sparks, 2003), consumers are constrained by habitual shopping behaviors. Thus, operations management enables the basis for experimenting with new exclusive online promotion innovations. We must also recognize that the historic, embedded, retail structures mean that consumers may remain 'captured' by habitual shopping behaviours and stores: the latter, in emerging markets, often offer the attraction of free minibus transport (or free scooter delivery) to stores/picking points/home. Therefore we propose that:

H3: The lower the consumers' expectations of resistance to change for online provision, the greater the online logistic promotion expectation.

\section{(4) Expectations for Online Convenience}

Time management, especially in urban environments, is defined as "behaviours that aim at achieving an effective use of time while performing certain goal-directed activities" (Claessens et al, 2004: 262). Time management is becoming a strategic variable of the 
consumer lifestyle. It is recognized that the way consumers handle the passage of time and the pursuit of goals fluctuates widely. Consumers with multiple workloads (work and study, work and family) tend to multitask so as to balance priorities and necessities. In addition, the temporal requirements of work (e.g. dual income family) together with the constraints of metropolises such as Istanbul (e.g. traffic, commuting distances) are further structuring time (i.e. link activities on the go - link shopping) that from a logistic perspective require further integration of the supply chain and integration of activities by vendors. Global technologies have also increased competition (sourcing convenience) and demands for immediate availability of products and services at any time and any place. As time is intangible, what can be influenced is the way a consumer deals with time. Thus, online provision models encompass automated enterprise resource planning systems (Chen et al., 2007). This practice results in efficient linkages between 'back office' and 'front office' systems through user friendly web interfaces. A yet further dimension is that wealthy but time-poor online consumers in cities such as Istanbul are willing to pay premium prices to place online orders and delivery at home or at the office at any time of the day (Rohm and Swaminathan, 2004). Thus, we propose the following hypothesis:

H4: The higher the consumers' expectations of time management, the greater the expectation for online logistic convenience provision.

\section{(5) Expectation for Alternative Collection Points}

The provision of secure, often manned, collection points in key locations such as around the city centre transport nodes, busiest shopping streets and offices areas (e.g. financial centres) must be integrated into the operations management of the retail firm (e.g. underground car parks), located across multiple local locations to cover a metropolis of $12+$ million and to 
adjust to the increasingly complex mobile lifestyles. Moreover, local retail infrastructure service levels, quality, and experiences in boutique shops of international brands need also to be emulated online. Thus, we offer the following hypotheses:

H5a: The higher the consumers' expectations of time management, the greater the expectation for alternative collection points.

Local retail infrastructure affects consumer patronage (Palmer et al., 2010). Recognizing that consumers' expectations account for both utility and meaning in the shopping provisions (i.e., varying across special occasions, everyday top-up shopping and once a week main shopping), studies suggest that more established shopping routines will lead to greater expectation for online operation provision. Therefore the provision of flexible convenient, secure collection points becomes an attractive asset and source of operational advantage.

H5b: The higher the resistance-to-change in service quality regarding online grocery practices compared to offline, the greater the expectation for manned alternative collection points.

The literature refers to the crucial operational process towards repeat purchase and sustainability as the last mile. Also options such as usage of neighbors, porters, security personnel offer potential alternative manned delivery points for consumers; online retailers resist these practices due to possible litigation, quality and insurance issues. In view of that bottleneck, for traditional grocery items, online consumers are open to convenient alternatives such as delivery points often located in convenient areas outside their home district on "their commuting routes".

H5c: The greater the constraint on collection points near the home, the greater the expectation for alternative collection points. 
Lastly, when top-up shopping is difficult due to the low provision of retail infrastructure, which is often the case in newly developed areas, where retail infrastructure follow dwelling constructions, or in low density population areas, efficient alternative delivery points are paramount to online retail models

H5d: The lower the availability of local retail stores around home area, the higher the expectation for alternative collection points outside the home area.

\section{Methodology}

(1) Data collection

Data for this study were collected via a phone survey in 2010 handled by a highly ranked market research agency. Participants were adults residing in the metropolis of Istanbul where online grocery shopping by two large supermarkets and a wide range of independents has been available since 2001. The recruitment criteria were based on two combined factors: online grocery shopping of at least three times a year (self-defined by respondents) and, role as primary household shopper. Data were collected via a convenience sample during a onemonth (November) period $(\mathrm{n}=356)$.

\section{(2) Research constructs and Items}

The questions, except categorical ones, were measured on a 5-point Likert scale anchored by 1 (strongly disagree) and 5 (strongly agree). Six items relate to logistics organizational procedure expectations and were adopted from Ha and Stoel (2009) to tap into the general operational procedures including the cleanliness of the transport vehicle and delivery personnel, refrigeration, damage to items and payment security. Three items were developed from Punakivi and Tanskanen (2002) to address the 'last mile delivery' expectations of collection points outside the home area. Four items addressing resistance-to-change were developed based upon previous work by Oreg (2006) in order to assess the impact of offline 
service quality and behaviour on online grocery purchasing. Five items were adopted from Jackson et al. (2006) and Rohm and Swaminathan (2004) to measure convenience expectation. Three items based on Clarke et al. (2006) and Rohm and Swaminathan (2004) measured the time management preferences of online grocery shoppers. Three items related to logistic promotion expectation were developed following Close and Kukar-Kinney (2010). Three items intended to tap into the premium expectation of online grocery shoppers were developed based on Silverstein and Fiske (2005) and Kapferer and Bastien (2009) including innovativeness, price, product alternatives and online communities. Three items regarding collection points around home were based on Punakivi and Tanskanen (2002). Three items on local retail infrastructure level were based on Clarke et al. (2006). Three items on purchase intentions from Park and Kim (2003) were also included as well as the collection of demographic data. The survey was translated to Turkish and pre-tested in an iterative manner amongst a sample of colleagues and students. Based on feedback, some questions were amended for clarity. A market research company implemented the survey through telephone interviews. Full anonymity was provided following our institution's ethical guidelines.

\section{(3) Respondent demographics}

The study measured a number of demographic variables in order to categorize the respondents and provide some notion of external validity for the results (Plank et al., 1999). The age variable was divided into five groups; the largest respondent group, with a 53.7\% was 25-34 years. Younger respondents up to 24 years of age constituted $15.7 \%$; respondents aged 35-44, $22.8 \%$. Lastly, $7.0 \%$ of respondents were $45-60$ and only $0.8 \%$, more than 60 years. Gender was evenly distributed: $52.8 \%$ males and $47.2 \%$ females. Education levels were $48.9 \%$ with undergraduate degree and $38.5 \%$ with high school degree. Household income ranged from $42.9 \%$ between 2500 TL-5000 TL to $40.9 \%$ between 1500 TL-2500 TL ( 1 TL=1.8USD). The metropolitan nature of the sample (upwards) biased the range but equates to many urbanite 
populations in emerging markets. Regarding dwelling, 79.2\% live in multi-storey apartments; $19.4 \%$ in a secured site; and only $1.4 \%$ in a single villa within gated communities. Furthermore, $56.7 \%$ of respondents are homeowners and $41 \%$ renters. Finally, $41.3 \%$ of the respondents claimed that they had to fit their shopping delivery / collection around paid work with $92.5 \%$ working full time.

According to the data, the average online grocery shoppers' basket size is between 70$150 \mathrm{TL}$ for $54.5 \%$ of the sample. Regarding frequency, 5-6 purchases per year represents $54.2 \%$ of the sample. Moreover, the data demonstrate that $38.2 \%$ buy up to $10 \%$ of their total grocery online, $24.7 \%$ buy $20 \%$ and $20.5 \%$ buy $30 \%$. A non-negligible proportion $16.5 \%$, buy online over $40 \%$ or more of their groceries.

\section{Results}

To ascertain the validity of the scales, confirmatory factor analysis (CFA) was conducted (Gerbing and Anderson, 1988). The CFA analysis confirmed that each construct had unidimentionality (low $\chi 2$, high p-value, and high-fit indexes). Convergent validity was also established as all items for each scale loaded significantly (with the lowest t-value being 3.978). Tables 1 and 2 present the scale items, correlations reliability, and descriptive statistics. The 10 factors identified include (1) expectation regarding logistic organizational procedure (2) collection points outside the home, (3) resistance to change, (4) convenience expectation, (5) time management, (6) promotion expectation, (7) premium expectation, (8) collection points around home, (9) local retail infrastructure and (10) purchase intention.

Insert Table 1 about here: Measures

And Table 2 about here: Correlations Reliability and Descriptive Statistics

Relationships between the constructs in the model were tested using structural equation modeling. In our model $\chi 2=766.26$ with 411 d.f. Following Wu (2006) our model's 
goodness of fit index equal to 0.88 , with a normed fit index of 0.83 , an adjusted goodness of fit index of 0.86 , and a comparative fit index of 0.91 demonstrating a good fit. Lastly, the model's root mean square error of approximation at 0.047 also indicates a good fit. The path coefficient and corresponding t-values along with the fit indices are presented in Table 3.

Insert Table 3 about here: Results of the SEM

The results indicate that the model is robust since all items were loaded significantly at the 0.01 level on their assigned latent variable. Table 3 demonstrates that logistic organizational procedure expectation positively impacts e-grocery purchase intention $(\beta=0.15$, $\mathrm{t}=3.11$ ) confirming $\mathrm{H} 1 \mathrm{a}$; logistic organizational procedure expectation has a significant positive relation with premium expectation $(\beta=0.28, \mathrm{t}=3.89)$ supporting H2a. The hypothesized positive effect of convenience expectation on online grocery purchase intention $(\beta=0.11, \mathrm{t}=2.13)$ and premium expectation $(\beta=0.48, \mathrm{t}=5.52)$ were both also shown to be statistically significant respectively confirming $\mathrm{H} 1 \mathrm{~b}$ and $\mathrm{H} 2 \mathrm{~b}$. The paths from online logistics promotion expectation to online grocery purchase intention $(\beta=0.14, \mathrm{t}=2.29)$ and premium expectation $(\beta=0.23, \mathrm{t}=2.63)$, respectively were significant as hypotheses $\mathrm{H} 1 \mathrm{c}$ and $\mathrm{H} 2 \mathrm{c}$. The path of collection points outside the home has a negative relationship with premium expectation $(\beta=-0.18, \mathrm{t}=-2.40)$, supporting $\mathrm{H} 2 \mathrm{~d}$. Time management has a significant positive effect on convenience expectation $(\beta=0.30, t=3.88)$ and a positive effect on collection points outside the home $(\beta=0.31, \mathrm{t}=4.42)$, confirming $\mathrm{H} 4$ and H5a. Resistance to change was shown to be negatively impacting online logistic promotion expectation $(\beta=-0.33, \mathrm{t}=-4.19)$ as hypothesized in $\mathrm{H} 3$, and had a positive relationship with collection points outside the home $(\beta=0.30, t=4.11)$ supported H5b. Lastly, the question of collection points around the home is shown to be positively influencing, collection points outside the home $(\beta=0.29, t=3.89)$, 
supporting $\mathrm{H} 5 \mathrm{c}$ respectively, whereas collection points around the home are negatively impacted by local retail infrastructure $(\beta=-0.22, \mathrm{t}=-2.95)$ as hypothesis $\mathrm{H} 5 \mathrm{~d}$.

\section{Discussion}

As the scale and scope of new technology usage in online grocery provision increases, it is important to understand the interplay between the geography, technology and power in (online) retailing practice. The findings show that consumers' shopping expectations intensify pressures to hybridize the operating model for online grocery provision of retail firms. The analysis also provides empirical support that consumers have unmet shopping expectations in relation to the choice of range offered through online operations. Rather than price as the main driver of consumer shopping expectations, the findings illustrate the complex decision making behaviour displayed by consumers' shopping expectations for online grocery provision. This paper is therefore an important step in this respect. Our empirical analysis in Turkey revealed the effect of online consumers' general expectations in emerging market conditions as well as an evaluation of the rising importance for the provision of premium grocery products. We find that consumers' expectations led to intensified agentic tensions and pressures on e-retail firms to hybridize logistic operating models for online grocery provision. Our analysis also provides empirical support to the argument that consumers (in particular the millennial and generation txt) have unmet expectations in relation to the choice of goods, especially regarding access to premium products as the emerging online platform has created new shopping patterns regarding both information and experience (Rheingold, 2002).

The results suggest that the following aspects of online logistic grocery operation: (i) the value of delivery point flexibility both around and outside the home, (ii) the impact of the offline retail infrastructure services or lack of them, and (iii) premium provision. These attributes include the significance of premium provision offerings, multiple sourcing actors, 
order consolidation points, along with flexible collection points leveraging the complexity of 'last mile' delivery. Power differentials are thus reversed, giving consumers control over which products retailers list. Word of mouth (WOM) and social networking sites via wireless access mainly through Smartphone are providing unprecedented control by ensuring that consumer demands are heard and acted upon. Our findings also carry implications for online retail providers seeking to make sense of emerging complex online behaviour. Among the more notable issues would be the need to extend choice whilst reducing operational duplication in order to achieve logistical effectiveness within the new metropolis geographical settings. A way ahead would be a partnership perspective that fosters collaboration across business entities. Typically, however, online grocery retail firms appear to be reluctant to engage in such scenarios that apparently deviate from their core business model. Indeed, many do not permit customers to diverge from listed items, regardless of any demand-led premium expectations.

In this paper, the mechanics of time management mediated by technology are considered. H4 underlines the technical aspect of online ordering through streamlined ordering process (flow) to reduce errors, thus allowing consumers to manage increasingly complex lifestyles. As such, it is fairly easy for respondents to evaluate and self-report on their perception of classical website performance (organization, logic, and check out process). H5a deals specifically with the logistics aspect of time management related to 'having options'. For many consumers, stopping by the supermarket or accessing click $\&$ collect may not be an option. Autonomy to shop for grocery items is often low in metropolises (e.g. lack of access to private transport, traffic preventing execution of one's original plan, location of large supermarkets, no fixed time for ending workday etc). In addition, in the case of grocery, household total needs have to be integrated, to acquire in one-time the maximum number of 
individually identified specific items, necessitating aggregation (multiple logins) to address the social context and personal mobility relations among individuals (Elms and Tinson, 2012). Taken together, alternative collection points offer a greater range of opportunities and a greater chance for one member of the family to collect the ordered grocery without changing one's schedule. Flexibility in a collection point is also relatively easy for respondents to identify as present, absent, or difficult/easy to specify on the website. Indeed, new field entrants such as Amazon are re-visiting such conventions (multiple addresses) with success and have created the notion of affiliate marketing (multiple sourcing vendors). The results identify a need for flexible delivery options to serve the dynamic socio-spatial environment in emerging markets. Our model specifically demonstrates that premium provision expectations and operational logistics are highly relevant in assessing consumer intentions towards online grocery purchases. However, we are concerned that current operational practices do not adequately meet the expectations of consumers in environments such as Istanbul. In Istanbul, the core actors have yet to venture truly in the wider digital ecosystem to fully understand the emerging role and potential of e-consumers. Powerful players may simply not be aware of the scale of change and the potential that it brings. The rapid growth of Yemeksepeti.com $[a$ meal in a basket] can be underlined here, as the main e-grocers have yet to integrate new wider field players in their organizational strategy (De Kervenoael and Dogerlioglu Demir, 2011).

The results also indicate the significance of advanced logistic operations models in extending choice and reducing operational duplication to achieve logistical effectiveness beyond traditional store planning systems. That is, logistic operational flexibility is a potentially rich source for profitably expanding consumer provision beyond the boundaries of the firm and the current limited choices. Indeed, studies on the recent success of the organic category, both food and non-food, demonstrate that price sensitivity has declined for premium 
products: a discovery that leads to a rethink of the traditional business model. Our results show that retail firms arbitrage of worldwide operations and information systems, for the most part directed towards cost reduction rather than increasing online grocery provision, may be un-justified. We suggest that the narrow view of provision adopted by online grocery providers should be broadened towards a partnership perspective that fosters collaboration across business entities, cross-functional teams, to improve logistical services. The end result would be a seamless, common share process that recognises the new momentum generated by consumers. The results, in turn, suggest a focus on total system performance rather than narrower cost based strategies and inclusion of the perspective of current and potential consumers would centralize consumer lead practices to new organizational strategies.

Viewed from another perspective, this study provides theoretical and empirical support for understanding which aspects or dimensions of consumers' expectations are critical (i.e. unmet expectations) to future business practices management innovation and planning policies demonstrating that consumers are now sufficiently strong (even if dispersed and uncoordinated) to significantly influence changes in the field. At the same time, however, this research indicates that online grocery retail firms will not necessarily engage in anticipating, experimenting, or determining which new consumer practices might result in a competitive advantage (Swidler, 1986). This lack of management innovation is perhaps because of (a) an oversight of the collective powers and roles of consumers and (b) a strong reluctance to see logistics partners as value-added associates under uncertain long term legal perspectives. Furthermore, myopic and management-centric views may under appreciate the powerful role of geography in shaping consumers' expectations.

Although the operations-enabling technologies are actually present (e.g. RFID, GIS, GPS), online grocery retail firms appear to be cautious and reluctant to engage in scenarios that deviate from their core business model and re-define firm boundaries (Lawrence and 
Phillips, 2004). This study appears to support the need for the new hybridization of a logistical operational model to emerge in practice encouraging technical interoperability a notorious weak point for e-grocers. The current logistic models do not permit customers to diverge from listed items, regardless of any demand-led premium expectations and hyperconnectivity with multiple providers. At another level, online provision is now driven by a multimedia global environment that encourages online retailers to go beyond their traditional pushing of technologies purely to grow sales. The operating models therefore must evolve to both meet the higher value expectations in the online provision via flexible delivery options that integrate emerging market dynamic socio-spatial environment away from the anticipated direction by the industry. As a result, our model specifically demonstrates that premium provision expectations and operational logistics are highly relevant in assessing the intention towards grocery purchase online creating social practice stickiness that may be difficult to reverse when the novel interrelationships among a broader set of actors is established. Concurrently, however, there is growing concern that while current operational practices do not adequately meet the expectations of consumers others consumers' practice that modify field-level custom and forces change are to be expected in other organization areas such as advertising, customer relationship management and new product development (von Hippel, 2005; Bijker and Law, 1997).

The hybridization of operating models which is a final implication relating to whether both models -- in-store picking and the distribution centre -- are operationally ill-equipped, individually, to account for the changing demography, growing choice and increasing expectations for the provision of premium offerings in emerging market metropolises. This study appears to support the need for a new hybridization operational model emerging in practice. The current operational models do not permit customers to diverge from listed items, regardless of any demand-led premium expectations may lead to greater sustainable growth. 
The findings suggest that business operation models that facilitate premium sense making and, in the process, encourage appreciation of the local culture and acquisition of a premium products that ultimately facilitate and progress consumers' expectations. At another level, online provision is now driven by a multimedia global environment that encourages online retailers to think and go beyond their traditional listed suppliers, yet the controlling size of the major players seems to inhibit operational logistic innovation. Online grocery retailers do not provide a forum for future suggested provision and providers. The operation model therefore must evolve to both meet the higher value expectations in the online provision via multiple delivery options and integrate urban transport flows as well as existing retail infrastructures.

\section{Limitations}

Consider a number of limitations in the present study. The study here examines only the effects of expectation on online grocery provision. Studies show that retail firms operating within advanced institutional retail structures are diversifying into non-grocery provision (Dawson et al., 2006; Elms et al., 2010). The sample of the study is based in Istanbul within Turkey; urban scholars argue that firms and therefore associated studies are extreme in their adherence to urban areas, neglecting rural areas and the associated operational constraints. Third, this study did not explore the underlying psychological processes by which expectations and online premium provision in general, affect consumers. A different study may elicit the responses of managers to understand the specific operational and information constraints of the online operation models.

\section{Conclusion}

The results suggest that while traditional aspects of online logistic grocery operation remain important, the following are also significant: (i) the value of delivery point flexibility 
both around and outside the home, (ii) the impact of the offline retail infrastructure services or lack of it, and (iii) premium provision. These attributes include the significance of premium provision offerings, multiple sourcing actors, order consolidation points, along with flexible collection points leveraging the complexity of the last mile delivery.

From a managerial perspective we identify two strategic management implications:

The results indicate the significance of advanced logistic operation models in extending choice and reducing operational duplication to achieve logistical effectiveness. That is, logistic operational flexibility is a potentially rich source for expanding consumer provision beyond firm boundaries and current limited choices at a profit. Our results show that retail firms arbitrage of worldwide operations and information systems, for the most part directed towards cost reduction rather than increasing online grocery provision, may be un-justified. We suggest that the narrow view of provision adopted by online grocery providers should be broadened towards a partnership perspective that fosters collaboration across business entities, cross-functional teams, to improve logistical services at that the whole activity ought to become a seamless common share process. The results, in turn, suggest a focus on total system performance rather than the narrower cost based strategies and that strategies that include the perspective of current and potential consumers are needed.

At the same time, however, this research indicates that online grocery retail firms will not necessarily engage in anticipating, experimenting, or determining which new consumer expectations might result in a competitive advantage. This lack of management innovation is perhaps because of a strong reluctance to see logistics partners as value added associates under uncertain long term legal perspectives. Although the operational enabling technologies are actually present (e.g. RFID, GIS, GPS), online grocery retail firms appear to be cautiously reluctant to engage in such scenarios that apparently deviate from their core business model. The operating models therefore must evolve to both meet the higher trading-up value 
expectations in the online provision via flexible delivery options that integrate emerging market dynamic socio-spatial environment. Inter-relationships and interdependencies introduced along the supply chain towards wider provision need to be integrated operationally and not resisted by online grocery retailers. The evolution of online retail provision is complex and operationally growing more sophisticated daily. Developments such as reverse logistics which can handle recycled products, storage of consumers' items (e.g., ski, windsurf board), and peer to peer exchanges are changing the meaning of logistics and the expectations consumers have of online operational models. Inter-relationships and interdependencies that introduced along the supply chain towards wider provision need to be integrated operationally and not resisted by online grocery retailers. Significantly however, concern is growing that current operational practices do not adequately meet the expectations of online consumers

\section{References}

Agatz, N.A.H.; Fleischmann, M.; and van Nunen, J.A.E.E. 2008. E-fulfillment and multichannel distribution - A review. European Journal of Operational Research, 187: 339-356.

Ansari, S. and N. Phillips. 2011, "Text me! New consumer practices and change in organizational fields". Organization Science 22(6): 1579-1599.

Aydemir, A. 2010. “Turkey's Internet censorship problem", http://www.todayszaman.com/news217435turkeysinternetcensorshipproblem. html, Access: October, 2012.

Berman, B., and Thelen, S. 2004. A guide to developing and managing a well integrated multichannel retail strategy. International Journal of Retail and Distribution Management, 32 (3): 147-156.

Bijker, W.,and J. Law. 1997. Shaping technology/building society. MIT Press, MA, USA. 
Bouzarovski, S., Salukvadze, J. and M. Gentile. 2010. A socially resilient urban transition? The contested landscapes of apartment building extensions in two post-communist cities. Urban Studies 48(13): 2689-2714.

Braysy, I., and Gendreau, M. 2005a. Vehicle routing problems with time windows, part I: Route construction and local search algorithms. Transportation Science, 39(1), 104118

Braysy, I., and Gendreau, M. 2005b. Vehicle routing problems with time windows, part II: Metaheuristics. Transportation Science, 39(1), 119-139

Burt, S., and Sparks, L. 2003. E-commerce and the retail process: A review. Journal of Retailing and Consumer Services, 10: 275-286

Cheema, A., and P. Papatla. 2010. Relative importance of online versus offline information for Internet purchases: Product category and internet experience effects. Journal of Business Research 63: 979-985.

Chen, M.C.; Yang, T.; and Li, H.C. 20074. Evaluating the supply chain performance of ITbased inter-enterprise collaboration. Information \& Management, 44: 524-534.

Claessens, B.J.C., van Eerde, W., Rutte, C.G.R., Roe, A. 2007. A review of the time management literature, Personnel Review, 36(2):.255 - 276.

Clarke, I. 2000. Retail power, competition and local choice in the UK grocery sector. European Journal of Marketing, 34: 975-1002

Clarke, I., Hallsworth, A., Jackson, P., De Kervenoael, R., Perez del Aguila, R. and M. Kirkup, 2006. Retail restructuring and consumer choice 1. Long term local changes in consumer behaviour: Porthsmouth, 1980-2002. Environment and Planning A 38: 2546.

Close, A. G., and M. Kukar-Kinney. 2010. Beyond buying: Motivations behind consumers” online shopping cart use. Journal of Business Research 63: 986-992. 
Collier, B. J., and C. C. Bienstock. 2006. How do customers judge quality in an E-tailer? MIT Sloan Management Review 48: 35-40.

Competition Commission. 2008. The Supply of Groceries in the UK market investigation.

Constantinides, E. 2004. 'Influencing the online consumer's behaviour: The web experience', Journal of Internet Research, 14 (2): 111-126.

Darke, P.R., and Chung, C.M. 2005. Effects of pricing and promotion on consumer perceptions: it depends on how you frame it. Journal of Retailing, 81(1): 35-47.

Daugherty, P.J., 2011. Review of Logistics and supply chain relationship literature and suggested research agenda. International Journal of Physical Distribution and Logistic Management 41(1): 16-31.

Dawson, J., Larke, R., and Mukoyama, M. 2006. Strategic Issues in International Retailing. Oxon: Routledge.

De Kervenoael, R, and Kivilcim, Dogerlioglu Demir 2011. Championing co-production and co-creation of value: the Turkish case of "Yemeksepeti.com" i.e., "Meal in a basket.com”. Innovations: Technology, Governance, globalization Special Edition for the Global Entrepreneurship Summit, Entrepreneurship, Values, and Development, 7175.

De Kervenoael, R., Canning, C. Hallsworth, A. and Palmer, M. 2011. Challenging Market Conventions: Supermarket Diversification and Consumer Resistance in Children's Apparel Purchases", Journal of Fashion Marketing Management, 15(4):.464 - 485

Deloitte, 2010. Hidden heroes: Emerging retail markets beyond China. 34 pages; A Consumer Business and Transportation industry report.

Economist 2013. The end of the space race, Britain's biggest retailer tries to adapt to fast$\begin{array}{llll}\text { changing } & \text { shopping } & \text { habits, } & \text { April }\end{array}$ 
http://www.economist.com/news/britain/21576441-britains-biggest-retailer-triesadapt-fast-changing-shopping-habits-end-space.

Elliot, S., and Fowell, S. 2000. "Expectations versus reality: a snapshot of consumer experience with internet retailing", International Journal of Information Management, 20 (5): 323-36.

Elms, J.; Canning, C.; de Kervenoael, R.; Whysall, P.; and Hallsworth, A. 2010. 30 years of retail change: where (and how) do you shop? International Journal of Retail and Distribution Management, 38, 11/12.

Elms J. and Tinson J. 2012 Consumer vulnerability and the transformative potential of Internet shopping: An exploratory case study, Journal of Marketing Management, 28 (11-12):. 1354-1376.

Eraydın, A. 2011. Changing Istanbul city region dynamics: re-regulations to challenge the consequences of uneven development and inequality. European Planning Studies, 19(5): 813-83.

Gerbing, D. W., and J. C. Anderson. 1988. An updated paradigm for scale development incorporating unidimensionality and its assessment. Journal of Marketing Research 25(2): 186-192.

Gulati, R., and Garino, J. 2000. Get the right mix of bricks and clicks. Harvard Business Review, 78 (3) (May/June): 107-114.

Ha, S. and L. Stoel. 2009. Consumer e-shopping acceptance: Antecedents in a technology acceptance model. Journal of Business Research 62: 565-571.

Hays, T and Keskinocak, P. 2004. Strategies and Challenges of Internet Grocery Retailing Logistics. Kluwer Academic Publishers, Dordrecht, The Netherlands.

Hollander, S. C. (1960). 'The Wheel of Retailing', Journal of Marketing, 24, pp. 37-42. 
Hsiao, M.H. 2009. Shopping mode choice: Physical store shopping versus e-shopping. Transportation Research Part E, 45: 86-95.

Jackson, P., Del Aguila, P. R., Clarke, I., Hallsworth, A., De Kervenoael, R., and M. Kirkup. 2006. Retail restructuring and consumer choice 2 . Understanding consumer choice at the household level. Environment and Planning A 38: 47-67.

Kamarainen, V., Saranen, J., and Holmstrom, J. 2001. The reception box impact on home delivery efficiency in the e-grocery business, International Journal of Physical Distribution and Logistics Management, 31 (6): 414-426.

Kapferer, J. N. and Bastien, V. 2009a The specificity of luxury management: Turning marketing upside down", Journal of Brand Management 16, 311-322.

Kapferer, J. N. and Bastien, V. 2009b The Luxury Strategy. London: Kogan Page.

Keller, K.L. (2009) "Building strong brands in a modern marketing communications environment", Journal of Marketing Communications, Vol 15, No 2-3, 139-155.

Keen, C.; Wetzels, M.; Ruyters, K.; and Feinberg, R. 2004. E-tailers versus retailers: Which factors determine consumer preferences? Journal of Business Research, 57: 685-695.

Kim, K.K.; Park, S. H.; Ryoo, S.Y.; and Park, S.K. 2010. Inter-organizational cooperation in buyer-supplier relationships: Both perspectives. Journal of Business Research, 63: 863-869.

Konrad, K. (2006), The social dynamics of expectations: the interaction of collective and actor-specific expectations on electronic commerce and interactive television, Technology Analysis and Strategic Management, 18 (3/4): 429-444.

Kotzab, H., and C. Teller. 2003. Value-adding partnerships and co-opetition models in the grocery industry", International Journal of Physical Distribution \& Logistic Management 33(3): 268-281.

URL: http:/mc.manuscriptcentral.com/cjol Email: ijlra@informa.com 
Lankenau, M.C.; Wehmeyer, K.; and Klein, S. 2005. Multi-Channel Strategies: Capturing and Exploring Diversity in the European Retail Grocery Industry. International Journal of Electronic Commerce, 10 (2): 85-122.

Lawrence, T. B., and N. Phillips. 2004. From Moby Dick to Free Willy: Macro-cultural discourse and institutional entrepreneurship in emerging institutional fields. Organization, 11(5): 689-711.

Macaulay, L.A.; Keeling, K.; McGoldrick, P.; Dafoulas, G.; Kalaitzakis, E.; and Keeling, D. 2007. Co-evolving E-tail and On-Line Communities: Conceptual Framework. International Journal of Electronic Commerce, 11 (4) (Summer): 53-77.

Murphy, A.J. 2007. Grounding the Virtual: The material effects of electronic shopping. Geoforum, 38: 941-953.

Nagy, G., \& Salhi, S. 2005. Heuristic algorithms for single and multiple depot vehicle routing problems with pickups and deliveries. European Journal of Operational Research, $162,126-141$.

Nagy, G., \& Salhi, S. 2007. Location-routing: Issues, models and methods. European Journal of Operational Research, 177, 649-672.

Oh, L-B., and Teo, H-H. 2010. Consumer Value Co-creation in a Hybrid Commerce Service Delivery System. International Journal of Electronic Commerce, 14 (3) (Spring): 3562.

Oreg, S. 2006. Personality, context, and resistance to organizational change. European Journal Work and Organizational Psychology 15(1): 73-101.

Palmer, M.; Owen, M.; and De Kervenoael, R. 2010. Paths of the Least Resistance: Understanding How Motives Form In International Retail Joint Venturing. The Service Industries Journal, 30: 965-989 
Park, C. H., and Y. G. Kim. 2003. Identifying key factors affecting consumer purchase behaviour in an online shopping context. International Journal of Retail and Distribution Management .31(1): 16-29.

Plank, R. E.; Reid, D. A.; and Pullins, E. B. 1999. Perceived trust in business-to- business sales: A new measure. Journal of Personal Selling and Sales Management, 19 (3): 6171.

Parragh, S. N., Doerner, K. F., \& Hartl, R. F. 2008. A survey on pickup and delivery problems, partI: Transportation between customers and depot. Journal für Betriebswirtschaft, 58(1), 21-51.

Parragh, S. N., Doerner, K. F., \& Hartl, R. F. 2008. A survey on pickup and delivery problems, part II: Transportation between pickup and delivery locations. Journal für Betriebswirtschaft, 58(2), 81-117.

Prasarnphanich, P., and Gillenson. M.L. 2003. The hybrid clicks and bricks business model. Communications of the ACM, 46 (12): 178-185.

Punakivi, M., and K. Tanskanen. 2002. Increasing the cost efficiency of e-fulfillment using shared reception boxes. International Journal of Retail and Distribution Management 30: $498-507$.

PWC, 2012. Intersections: Transportation and logistics industry merger and acquisitions http://www.pwc.com/us/en/industrial-products/publications/intersections.jhtml Accessed December 2012.

Ramus, K., and Nielsen, A. 2005. "Online grocery retailing: what do consumers think?", Internet Research, 15 (3): $335-352$.

Rheingold, H. 2002. Smart mobs. The next social revolution. MA, USA: Perseus Publishing. 
Richey Jr., R.G.; Tokman, M.; and Skinner L.R. 2008. Exploring collaborative technology utilization in retailer-supplier performance. Journal of Business Research, 61: 841849.

Rohm, A. J. and V. Swaminathan. 2004. A typology of online shoppers based on shopping motivations. Journal of Business Research .57: 748-757.

Rotem-Mindali, O. 2010. E-tail versus retail: The effects on shopping related travel empirical evidence from Israel. Transport Policy, 17: 312-322.

Saeed, K.A.; Grover, V.; and Hwang, Y.2003. Creating synergy with a clicks and mortar approach. Communications of the ACM, 46 (12): 206-212.

Sanchez, J. A., Vijande, M. L., and J.A. Gutierrez. 2010. The impact of relational variables on value creation in buyer-seller business relationships. Journal of Business-to-Business Marketing 17: 62-94.

Shih, H.P. 2004. An empirical study on predicting user acceptance of e-shopping on the web, Information \& Management, 41: 351-368.

Silverstein, M. J., and N. Fiske. 2005. Trading up: Why consumers want new luxury goods, and how companies create them. (rev. ed.), New York: Portfolio.

Swidler, A.1986. Culture and Action: Symbols and Strategies. Amer. Sociol. Rev. 51(2), pp. 273-286.

Tsou, H-T. 2012. The effect of interfirm codevelopment competency on the innovation of the e-service process and product: the perspective of internal/external technology integration mechanisms. Technology Analysis and Strategic Management, 24(7): 631646.

Tungate, M. 2004. Fashion Brands: Branding Style from Armani to Zara. London: Kogan Page. 
Yanik, S., Bozkaya, B., and R. de Kervenoael. 2014. A New VRPPD Model and a Hybrid Heuristic Solution Approach for ETailing. European Journal of Operational Research 236(3): 879-890.

Venkatesh, V.; Morris, M.G.; Davis, G.B.; and Davis, F.D. 2003. User acceptance of information technology: Toward a unified view. MIS Quarterly, 27: 425-478.

von Hippel, E. 2005. Democratizing Innovation. Cambridge, MA, MIT Press.

Vroom, H. V. 1964. Work and Motivation, John Wiley\&Sons Inc. USA.

Vroom, V. 1964. On the Origin of the Expectancy Theory. In K. G. Smith and M. A. Hitt (Eds.), Great Minds in Management UK: Oxford University Press, (2005), 239-259. 
FIGURE 1

A MODEL OF CONSUMERS' EXPECTATIONS FOR ONLINE RETAIL PROVISION

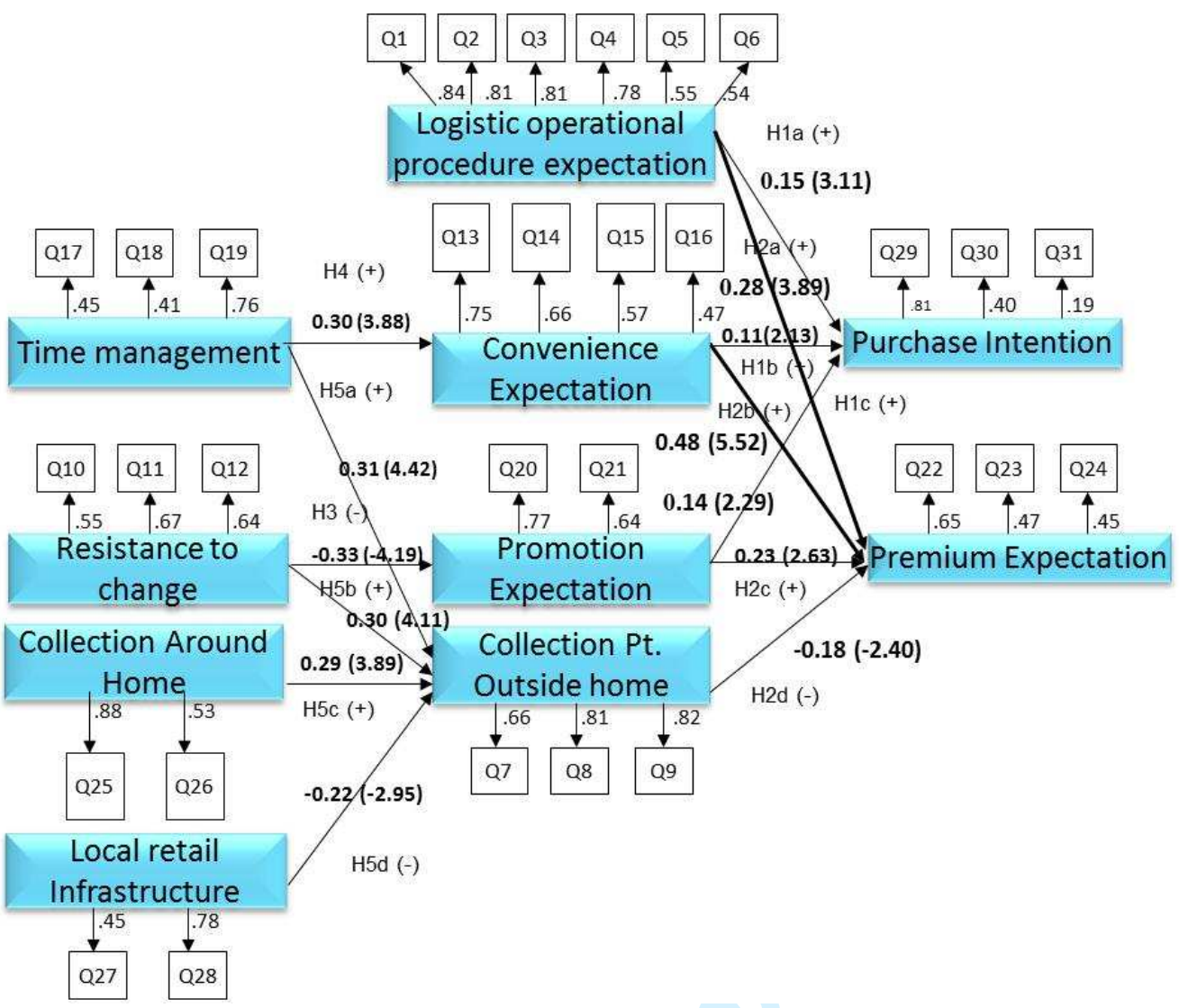

URL: http:/mc.manuscriptcentral.com/cjol Email: ijlra@informa.com 
Table 3. Results of the SEM

\begin{tabular}{|c|c|c|c|}
\hline Hypotheses & Path & Path Value & Result \\
\hline Hypothesis 1 & $\begin{array}{ll}\text { Logistics Org. Pr. Exp. } \rightarrow \text { Purchase Intention } \\
\text { Convenience Exp. } & \rightarrow \text { Purchase Intention } \\
\text { Logistics Prom. Exp. } & \rightarrow \text { Purchase Intention }\end{array}$ & $\begin{array}{l}.15^{* * *} \\
.11^{* *} \\
.14^{* *}\end{array}$ & Supported \\
\hline Hypothesis 2 & $\begin{array}{ll}\text { Logistics Org. Pr. Exp. } \rightarrow \text { Premium Exp. } \\
\text { Convenience Exp. } & \rightarrow \text { Premium Exp. } \\
\text { Logistics Prom. Exp } & \rightarrow \text { Premium Exp. } \\
\text { Collection Pt. Out. H. } & \rightarrow \text { Premium Exp. }\end{array}$ & $\begin{array}{l}.28^{* * *} \\
.48^{* * *} \\
.23^{* *} \\
-.18^{* *}\end{array}$ & Supported \\
\hline Hypothesis 3 & Resist. to change $\quad \rightarrow$ Logistics Prom. Exp. & $.33^{* * *}$ & Supported \\
\hline Hypothesis 4 & Time management $\rightarrow$ Convenience Exp. & $.30^{* * *}$ & Partially supported \\
\hline Hypothesis 5 & $\begin{array}{l}\text { Time management } \rightarrow \text { Collection Pt. Out. H. } \\
\text { Resist. to change } \rightarrow \text { Collection Pt. Out. H. } \\
\text { Collect. Pt. Ar. H. } \rightarrow \text { Collection Pt. Out. H. } \\
\text { Local Retail Infr. } \rightarrow \text { Collection Pt. Out. H. }\end{array}$ & $\begin{array}{l}.31^{* * *} \\
.30^{* * *} \\
.03^{* * *} \\
-.22^{* *}\end{array}$ & \\
\hline Fit measures & Endogenous constructs & Main model & \\
\hline$R^{2}$ & $\begin{array}{l}\text { Collection Pt. Out. H } \\
\text { Convenience Exp. } \\
\text { Logistics Prom. Exp. } \\
\text { Premium Exp. } \\
\text { Purchase Intention }\end{array}$ & $\begin{array}{l}.40 \\
.09 \\
.11 \\
.39 \\
.08\end{array}$ & \\
\hline & $=1.98, \mathrm{GFI}=.88, \mathrm{CFI}=.91, \mathrm{~N}$ & $\mathrm{AFI}=.86, \mathrm{R}$ & $E A=.047$ \\
\hline
\end{tabular}


Table 2. Correlations Reliability and Descriptive Statistics

\begin{tabular}{|c|c|c|c|c|c|c|c|c|c|c|c|c|c|}
\hline Mean & S.Dev & & Variables & 1 & 2 & 3 & 4 & 5 & 6 & 7 & 8 & 9 & 10 \\
\hline 2.84 & 0.99 & 1 & $\begin{array}{l}\text { Logistics Opr. } \\
\text { Pr. Exp. }\end{array}$ & $(.73)$ & & & & & & & & & \\
\hline 2.89 & 1.09 & 2 & $\begin{array}{l}\text { Collection pt. } \\
\text { Outside }\end{array}$ & -.03 & (.77) & & & & & & & & \\
\hline 3.05 & 0.90 & 3 & $\begin{array}{l}\text { Resistance to } \\
\text { Change }\end{array}$ & $.14^{* * *}$ & $.30^{* * *}$ & (.61) & & & & & & & \\
\hline 4.20 & 0.57 & 4 & $\begin{array}{l}\text { Convenience } \\
\text { Expectation }\end{array}$ & $.18^{* * *}$ & -.003 & $.20^{* * *}$ & (.62) & & & & & & \\
\hline 3.42 & 0.90 & 5 & \begin{tabular}{|l} 
Time \\
Management \\
Logistics
\end{tabular} & .09 & $.23^{* * *}$ & .07 & $.20^{* * *}$ & $(.55)$ & & & & & \\
\hline 4.00 & 0.78 & 6 & $\begin{array}{l}\text { Promotion } \\
\text { Exp. }\end{array}$ & -.05 & $.09^{*}$ & $19^{* * *}$ & $.17^{* * *}$ & .02 & $(.72)$ & & & & \\
\hline 3.86 & 0.70 & 7 & $\begin{array}{l}\text { Premium } \\
\text { Expectation }\end{array}$ & $.15^{* * *}$ & $-.13^{* *}$ & $.16^{* * *}$ & $.28^{* * *}$ & .04 & $.18^{* * *}$ & (.53) & & & \\
\hline 2.93 & 1.07 & 8 & $\begin{array}{l}\text { Collection pt. } \\
\text { around Home }\end{array}$ & -.08 & $.37^{* * *}$ & $.16^{* * *}$ & .05 & .05 & $-.10^{*}$ & $.08^{* * *}$ & (.69) & & \\
\hline 3.89 & 0.83 & 9 & $\begin{array}{l}\text { Local Retail } \\
\text { Infrastructure }\end{array}$ & .07 & $.20^{* * *}$ & .01 & $.11^{* *}$ & $.05^{* * *}$ & .08 & $.15^{* * *}$ & $.09^{*}$ & $(.60)$ & \\
\hline \multirow[t]{4}{*}{2.07} & 0.96 & 10 & $\begin{array}{l}\text { Purchase } \\
\text { Intention }\end{array}$ & $.13^{* *}$ & -.01 & $.29^{* * *}$ & .04 & .09 & $.12^{* *}$ & .01 & -.02 & -.07 & $(.74)$ \\
\hline & & & $\begin{array}{l}\text { Composite } \\
\text { reliability }\end{array}$ & .87 & .81 & .70 & .71 & .57 & .87 & .53 & .69 & .52 & .70 \\
\hline & & & Cronbach's $\alpha$ & .87 & .80 & .70 & .71 & .57 & .67 & .52 & .63 & .52 & .66 \\
\hline & & & AVE & .54 & .59 & .37 & .39 & .31 & .52 & .28 & .45 & .35 & .55 \\
\hline
\end{tabular}

URL: http:/mc.manuscriptcentral.com/cjol Email: ijlra@informa.com 
Table 1: SCALE ITEMS FOR ONLINE GROCERY CHOICE

\begin{tabular}{|c|c|}
\hline Name & Constructs \\
\hline \multirow{6}{*}{$\begin{array}{l}\text { Logistic } \\
\text { Operational } \\
\text { Procedure } \\
\text { Expectation }\end{array}$} & I think cleanness of online logistic delivery services (van) is a problem. \\
\hline & I think the cold chain in logistic delivery vehicles is a problem. \\
\hline & I think cleanness of online grocery logistic delivery personnel is a problem. \\
\hline & I think the hot weather is a problem in Turkey for logistic grocery delivery. \\
\hline & $\begin{array}{l}\text { During my online grocery purchases, I am worried about the logistical security } \\
\text { of the financial transactions on the web and at the door via wireless POS. }\end{array}$ \\
\hline & $\begin{array}{l}\text { I am scared that my online grocery order will be tampered with during } \\
\text { transport. }\end{array}$ \\
\hline \multirow{3}{*}{$\begin{array}{l}\text { Collection Points } \\
\text { Outside Home }\end{array}$} & I would like special delivery boxes to be made available in/around my office. \\
\hline & I would like special collection boxes to be made available on the main roads. \\
\hline & $\begin{array}{l}\text { I would like special delivery boxes to be made on the main public transport } \\
\text { transit points. }\end{array}$ \\
\hline \multirow{4}{*}{$\begin{array}{l}\text { Resistance to } \\
\text { Change }\end{array}$} & $\begin{array}{l}\text { It would make little logistic difference to me if I had to stop shopping for } \\
\text { online grocery. }\end{array}$ \\
\hline & $\begin{array}{l}\text { To change my preference from store shopping to online shopping would } \\
\text { require major logistical rethinking. }\end{array}$ \\
\hline & I consider myself to be highly loyal to offline shopping. \\
\hline & $\begin{array}{l}\text { The convenience of local shops -free buses, delivery- is worth the extra it can } \\
\text { cost. }\end{array}$ \\
\hline \multirow{4}{*}{$\begin{array}{l}\text { Convenience } \\
\text { Expectation }\end{array}$} & Shopping online for groceries makes my life easier. \\
\hline & I shop for online grocery because I don't like to carry heavy bags. \\
\hline & Shopping online for groceries is an efficient way to manage my time. \\
\hline & $\begin{array}{l}\text { I prefer shopping online for groceries because it does not require a lot of } \\
\text { physical effort. }\end{array}$ \\
\hline \multirow{3}{*}{$\begin{array}{l}\text { Time } \\
\text { Management }\end{array}$} & I find shopping for my groceries very tiring. \\
\hline & I would prefer doing all my shopping just once a week. \\
\hline & I try to avoid walking for more than five minutes with my shopping. \\
\hline \multirow{2}{*}{$\begin{array}{l}\text { Promotion } \\
\text { Expectation }\end{array}$} & $\begin{array}{l}\text { I will shop more for online groceries if the retailers offer more free samples } \\
\text { test items and deliver free }\end{array}$ \\
\hline & $\begin{array}{l}\text { I will shop more for online groceries if the retailers propose special online } \\
\text { logistic promotions (free delivery to chosen location, office, home, others } \\
\text { points). }\end{array}$ \\
\hline \multirow{3}{*}{$\begin{array}{l}\text { Premium } \\
\text { Expectation }\end{array}$} & I would like to have online access to products that make me feel special. \\
\hline & I would like seasonal premium product. \\
\hline & $\begin{array}{l}\text { I would prefer to have online access to special international cuisine } \\
\text { ingredients. }\end{array}$ \\
\hline \multirow{2}{*}{$\begin{array}{l}\text { Collection Around } \\
\text { Home }\end{array}$} & $\begin{array}{l}\text { I would like the option for my online grocery orders to be delivered to my } \\
\text { home security/porter. }\end{array}$ \\
\hline & $\begin{array}{l}\text { I would prefer if my online grocery orders are given to my neighbor when I am } \\
\text { not at home. }\end{array}$ \\
\hline \multirow[t]{2}{*}{$\begin{array}{l}\text { Local Retail } \\
\text { Infrastructure }\end{array}$} & $\begin{array}{l}\text { There are already plenty of local food stores that deliver to choose from in this } \\
\text { area. }\end{array}$ \\
\hline & I can easily get to any food store I wish in my local area. \\
\hline
\end{tabular}

